\title{
Pressure-temperature conditions and significance of Upper Devonian eclogite and amphibolite facies metamorphisms in southern French Massif central
}

\author{
Anissa Benmammar ${ }^{1,2}$, Julien Berger ${ }^{1, a, *}$, Antoine Triantafyllou ${ }^{3,4}$, Stéphanie Duchene ${ }^{1}$, \\ Abderrahmane Bendaoud ${ }^{2}$, Jean-Marc Baele ${ }^{5}$, Olivier Bruguier ${ }^{6}$ and Hervé Diot ${ }^{7,8}$ \\ ${ }^{1}$ Géosciences Environnement Toulouse, Université de Toulouse, CNRS, IRD, UPS, Toulouse, France \\ 2 Department of Geology, Université des Sciences et de la Technologie Houari Boumediene, Algiers, Algeria \\ 3 Department of Geology, University of Liège, Sart Tilman, Liège, Belgium \\ ${ }^{4}$ Department of Geosciences, University of Arizona, Tucson, USA \\ ${ }^{5}$ Department of Geology and Applied Geology, Université de Mons, Mons, Belgium \\ ${ }^{6}$ University Montpellier, Géosciences Montpellier, UMR-CNRS-UM2 5243, Place Eugene Bataillon, 34095 Montpellier, France \\ ${ }^{7}$ LPGN, UMR-CNRS 6112, Université de Nantes, Nantes, France \\ ${ }^{8}$ Université de La Rochelle, La Rochelle, France
}

\begin{abstract}
The southwestern French Massif central in western Rouergue displays an inverted metamorphic sequence with eclogite and amphibolite facies units forming the top of the nappe stack. They are often grouped into the leptyno-amphibolite complex included, in this area, at the base of the Upper Gneiss Unit. We sampled garnet micaschists and amphibolites to investigate their metamorphic history with isochemical phase diagrams, thermobarometry and $\mathrm{U}-\mathrm{Pb}$ zircon dating. Our results demonstrate that two different tectono-metamorphic units can be distinguished. The Najac unit consists of biotite-poor phengitegarnet micaschists, a basic-ultrabasic intrusion containing retrogressed eclogites and phengite orthogneisses. Pressure and temperature estimates on micaschists with syn-kinematic garnets yield a prograde with garnet growth starting at $380^{\circ} \mathrm{C} / 6-7 \mathrm{kbar}$, peak pressure at $16 \mathrm{kbar}$ for $570^{\circ} \mathrm{C}$, followed by retrogression in the greenschist facies. The age of high pressure metamorphism has been constrained in a recent publication between ca. 383 and $369 \mathrm{Ma}$. The Laguépie unit comprises garnet-free and garnet-bearing amphibolites with isolated lenses, veins or dykes of leucotonalitic gneiss. Thermobarometry and phase diagram calculation on a garnet amphibolite yield suprasolidus peak P-T conditions at $710^{\circ} \mathrm{C}, 10 \mathrm{kbar}$ followed by retrogression and deformation under greenschist and amphibolite facies conditions. New U-Pb analyses obtained on igneous zircon rims from a leucotonalitic gneiss yield an age of $363 \pm 3 \mathrm{Ma}$, interpreted as the timing of zircon crystallization after incipient partial melting of the host amphibolite. The eclogitic Najac unit records the subduction of a continental margin during Upper Devonian. It is tentatively correlated to a Middle Allochthon, sandwiched between the Lower Gneiss Unit and the Upper Gneiss Unit. Such an intermediate unit is still poorly defined in the French Massif central but it can be a lateral equivalent of the Groix blueschists in the south Armorican massif. The Uppermost Devonian, amphibolite facies Laguépie unit correlates in terms of P-T-t evolution to the Upper Gneiss Unit in the Western French Massif central. This Late Devonian metamorphism is contemporaneous with active margin magmatism and confirms that the French Massif central belonged to the continental upper plate of an ocean-continent subduction system just before the stacking of Mississippian nappes.
\end{abstract}

Keywords: Variscan / Rouergue / HP metamorphism / partial melting

Résumé - Évolution pression-température et implications des métamorphismes amphibolitique et éclogitique du Dévonien supérieur dans le sud du Massif central français. Les unités tectonométamorphiques du sud-ouest du Massif central français, dans l'ouest du Rouergue, sont structurées selon

\footnotetext{
*Corresponding author: julien. berger@get.omp.eu

${ }^{a}$ Present address: Géosciences Environnement Toulouse, 14 avenue

Edouard Belin, 31400 Toulouse, France.
} 
une séquence métamorphique inverse où les unités du faciès éclogite et amphibolite se situent au sommet de l'empilement des nappes. Ces unités régionales sont généralement incorporées dans le complexe leptynoamphibolique, formant la base de l'Unité des Gneiss Supérieurs. Suite à une étude comparative de l'histoire métamorphique des unités de Najac et de Laguépie, deux unités tectono-metamorphiques peuvent etre distinguées. L'unité de Najac est composée de métapélites à phengite-grenat pauvres en biotite, d'une intrusion basique-ultrabasique renfermant des éclogites rétromorphosées et des orthogneiss à phengite. Le grenat commence sa croissance vers $380^{\circ} \mathrm{C} / 6-7 \mathrm{kbar}$, suivi d'un pic de pression à $16 \mathrm{kbar}$ et $570^{\circ} \mathrm{C}$ et enfin d'une rétromorphose dans les conditions du faciès des schistes verts. L'âge du métamorphisme de hautepression a été contraint récemment entre 383 et 369 Ma. L'unité de Laguépie est formée par des amphibolites avec ou sans grenat renfermant des lentilles isolées, des veines ou dykes de gneiss leucotonalitique. Les conditions $\mathrm{P}-\mathrm{T}$ ont été estimées sur une amphibolite à grenat à $710^{\circ} \mathrm{C}$ et $10 \mathrm{kbar}$ pour la fusion partielle suivie d'une rétromorphose et une déformation dans les conditions du faciès des amphibolites et des schistes verts. Les datations $\mathrm{U}-\mathrm{Pb}$ sur des bordures de zircons d'une veine de gneiss leucotonalitique donnent un âge de $363 \pm 3 \mathrm{Ma}$, interprété comme marquant la cristallisation magmatique des zircons après l'initiation de la fusion partielle de l'encaissant amphibolitique. L'unité de Najac a enregistré la subduction d'une marge continentale au Dévonien supérieur. Elle peut être corrélée à un Allochthone Intermédiaire, compris entre l'Unité des Gneiss Inférieurs et l'Unité des Gneiss Supérieurs. Une telle unité intermédiaire est encore mal définie dans le Massif central français mais elle peut être un équivalent latéral des schistes bleus de Groix dans le Massif Armoricain. L'unité amphibolitique du Dévonien Supérieur de Laguépie est reliée en termes d'évolution P-T-t à l'Unité des Gneiss Supérieurs dans le Massif Central français occidental. Ce métamorphisme du Dévonien tardif est contemporain d'un magmatisme de marge active et confirme que le sud du Massif Central français appartenait à la plaque continentale supérieure d'un système de subduction océan-continent juste avant l'empilement des nappes durant le Mississippien.

Mots clés : Varisque / Rouergue / métamorphisme HP / fusion partielle

\section{Introduction}

The evaluation of pressure-temperature-time paths in orogenic belts is fundamental to reconstruct the geotectonic evolution before, during and after the orogenesis. Specifically, pre-collisional eclogite and blueschist high-pressure (HP) units formed in the subducting slab (Ernst, 2001) and amphibolite to granulite high-temperature (HT) units belonging to the upper plate (Hydmann et al., 2005) may contain crucial information on the dynamics of pre-orogenic subductions (Brown, 2006). The stacking of these subduction-related HP and HT metamorphic rocks onto greenschist facies units during exhumation and/or collision can lead to the formation of inverted metamorphic sequences (Peacock, 1987) where metamorphic conditions increase upward in the tectonic stack and where the boundary between units is marked by localized deformation and sharp contrasts in metamorphic conditions.

Pioneer studies on the Variscan French Massif central (FMC) showed that pre-Visean metamorphic units have a complex tectonic distribution (see Burg et al., 1984, 1989; Ledru et al., 1989, 1994; Santallier et al., 1994; Faure et al., 2005, 2009; Lardeaux, 2014; Lardeaux et al., 2014), with greenschist facies units forming the lowermost and uppermost parts of the tectonic pile (the para-autochthon and the so-called epizonal units, respectively). Amphibolite facies units locally preserving relic of eclogites and HP granulites rocks are classically grouped into the Lower Gneiss Unit (LGU) and the Upper Gneiss Unit (UGU) in the French Massif central (see Bellot and Roig, 2007) but investigations on the neighboring Armorican massif (Bosse et al., 2000, 2005; Ballèvre et al., 2009; Pitra et al., 2010; Ballèvre et al., 2014) pointed out the existence of a Late Devonian ophiolitic and eclogite/ blueschist-bearing Middle Allochthon sandwiched between the upper and lower units. Berger et al. (2010a, 2010b) proposed to introduce a Middle Allochthon in the FMC located between LGU and UGU and composed of HP to UHP eclogites with host orthogneiss and micaschists but also of ophiolites marked by a post-oceanic equilibration in the granulite facies (Santallier et al., 1994; Berger et al., 2010b). This subdivision, still immature for the French Massif central, group together rocks with contrasted metamorphic evolutions. More detailed metamorphic petrology studies are thus needed to propose a better scheme of subdivision and coherent geodynamic interpretations. Furthermore, this metamorphic organization is not integrated in the most recent compilations on the metamorphic evolution of the French Massif central (Faure et al., 2009; Lardeaux, 2014) in which most HP metamorphic rocks are included within the Upper Gneiss Unit encompassing the enigmatic leptyno-amphibolite complex (Santallier et al., 1988). The latter is defined as a bimodal association of felsic and mafic gneisses frequently containing relics of eclogite and granulite facies rocks and often located at the base of UGU, sometimes in LGU. These apparent conflicting views are, on the one hand due to the poor quality of exposures in the French Massif central, and on the other hand to the lack of detailed quantitative metamorphic studies coupled to petrochronological investigations that are to propose robust pressuretemperature-time (P-T-t) paths.

Recent dating performed on eclogites from Southern Massif central yielded Upper Devonian to Lowermost Carboniferous ages (Lotout et al., 2018, 2020) while the HP metamorphism and the closure of oceanic domains in the French Massif central are classically considered to be around 410-390 Ma (Eo-varican cycle or D0 event of Faure et al., 2009; see also Lardeaux, 2014). Ages of HP metamorphism published between 1980 and 2000 have to be re-evaluated 
(Paquette et al., 2017) and, more generally, petrochronological data on metamorphic units are required to better constrain the Devonian evolution of the French Massif central. These data are crucial to determine if the West European Variscan belt is polycylic and marked by two phases of convergence and ocean closure (Faure et al., 2005, 2008, 2009; Lardeaux, 2014) or monocyclic with a single event of continental collision (Ballèvre et al., 2009) or somewhere between the two endmembers models.

This paper addresses the question of the subdivision of amphibolite and eclogite facies metamorphic units and their geological meaning in southern French Massif central near Najac in Western Rouergue (Burg et al., 1984, 1989). According to most authors, the metamorphic units in this area are thought to belong to the leptyno-amphibolite complex and are often integrated into the UGU (Lardeaux, 2014; Lotout et al., 2018). Our study shows that their constitutive rocks display contrasted P-T-t-d histories. Therefore, we provide new P-T estimations on phengite-garnet micaschists from Najac and on migmatitic amphibolites from Laguépie. These results are coupled to $\mathrm{U}-\mathrm{Pb}$ zircon dating in the latter unit and interpreted considering the new and robust multi-method ages provided by Lotout et al. (2018) on an eclogite from Najac.

\section{Geological setting}

The Variscan French Massif central consists of several tectono-metamorphic units that were stacked before the Visean (see Faure et al., 2009; Lardeaux, 2014). Despite the poor quality of their exposures, the metamorphic units are well defined on geological maps and in the literature in Limousin, Haut-Allier and Rouergue domains (Dubuisson et al., 1988; Ledru et al., 1989; Ledru et al., 1994; Burg et al., 1989a). This stack is characterized by an apparent inverse metamorphic gradient, with amphibolite facies and eclogite facies units (Lower Gneiss and Upper Gneiss Units; LGU and UGU, respectively) commonly lying above greenschist units (ParaAutochthon; see Burg et al., 1984; Lardeaux, 2014). At the scale of the French Massif central, the pre-Carboniferous tectono-metamorphic evolution is subdivided into three phases following (Faure et al., 2005, 2008, 2009, 2017): D0 represent the Late Silurian/Early Devonian (420-400 Ma) HP metamorphic phase; D1 relates to amphibolite facies migmatitization in LGU and UGU associated with a top-to-the-southeast kinematics, it occurred during Middle and Upper Devonian (385-375 Ma); D2 (360-350 Ma) is marked by top-to-thenorthwest kinematics under amphibolite facies conditions. However, recent petrochronological investigations performed by Lotout et al. $(2018,2020)$ yielded Upper Devonian to Early Carboniferous ages for HP metamorphism in southern French Massif central (Najac and Lévézou). These new findings suggest that the D1 and D2 phases as defined by Faure et al. (2009) are also contemporaneous with formation and exhumation of eclogites in southern French Massif central.

Outcrops of the Viaur and Aveyron valleys near Najac and Laguépie were described in details by Collomb (1970), Bodinier and Burg (1981) and Burg et al. (1984). The paraautochthon consists of greenschist facies metapelites (chloritemuscovite \pm biotite bearing) with rare intercalation of felsic, often meta-volcanic, orthogneiss (Fig. 1). The Lower Gneiss
Unit is separated from the para-autochthon by a low angle mylonitic shear zone. It is made of orthogneiss representing former felsic plutons with rare lenses of amphibolite facies biotite-muscovite \pm garnet metapelites. The contact with the Najac-Carmaux unit is not well exposed but it is interpreted as a thrust contact considering that the latter contains eclogite facies rocks that were not found in the Lower Gneiss Unit (see Burg et al., 1984). The Najac-Carmaux klippe as defined by Burg et al. (1984) consists of an association of phengite-rich micaschists (often garnet-bearing, with minor amounts of biotite and locally accompanied by chloritoid and staurolite; Delor et al., 1987), phengite-bearing porphyroclastic orthogneisses and basic-ultrabasic complexes known as the Najac and Laguépie massifs (Delor et al., 1986; Bodinier et al., 1986; Lotout et al., 2018). Bodinier and Burg (1981) and Bodinier et al. (1986) interpret the eclogitic layered intrusion south of Najac as a former laccolith that intruded the precursor of micaschists and orthogneiss prior to high-pressure metamorphism. We observed small (max $10 \mathrm{~cm}$ width) xenolithic fragments of phengite orthogneiss included into eclogite facies metagabbros south of Najac, close to Mergieux. This supports the conclusion considering the Najac basic-ultrabasic massif as a former intrusion within the orthogneiss. Bodinier and Burg (1981) and Bodinier et al. (1986) also noted that the Najac eclogitic basic-ultrabasic massif and the Laguépie amphibolite recorded distinct metamorphic histories but so far, no metamorphic studies have been performed on the amphibolites.

Hereafter, the phengite micaschists, the phengite orthogneiss and the eclogitized basic-ultrabasic intrusion cropping out south of Najac will be grouped into the Najac unit because they display a similar metamorphic evolution (Fig. 1; Burg et al., 1984; this study). The amphibolite massif west of Laguépie, devoid of HP mineral assemblage and showing evidence for incipient partial melting will compose the Laguépie unit. Both are either included within (1) the NajacCarmaux klippe/unit by Burg et al. (1984) and tentatively correlated to the Groix and Bois de Céné units in the Armorican massif (Delor et al., 1986), or (2) following Lardeaux (2014) and Lotout et al. (2018) they are part of the Leptyno-Amphibolite Complex (LAC) at the base of the Upper Gneiss Unit (Santallier et al., 1994; Lardeaux, 2014). The Laguépie unit is bounded by normal and strike-slip faults, its position within or relative to the Najac unit remains unclear but the normal faults suggest it was structurally located above the Najac unit.

Metamorphic foliations in the Viaur and Aveyron valleys are dipping to the east $\left(20-70^{\circ} \mathrm{dip}\right)$ except in the eastern part of the map (Fig. 1). They are affected by small scale overturned $\mathrm{N}-\mathrm{S}$ folds with an axial plane facing west. Stretching lineations are generally trending $\mathrm{N} 350$ with low plunges $\left(<10^{\circ}\right)$. Asymmetric criterion for sense of shear are well expressed along the mylonitic band separating the para-autochthon and the Lower Gneiss Unit is top-to-the-north (D2 phase of Faure et al., 2009). The eclogitic orthogneisses and micaschists of the Najac unit also carry a N280-300-trending stretching lineation with top-to-the-southeast kinematics (deduced from $\mathrm{C} / \mathrm{S}$ structures and asymmetric feldspar porphyroclasts in orthogneisses).

Northeast of Najac, the whole metamorphic massif is intruded by the Carboniferous Villefranche de Rouergue 


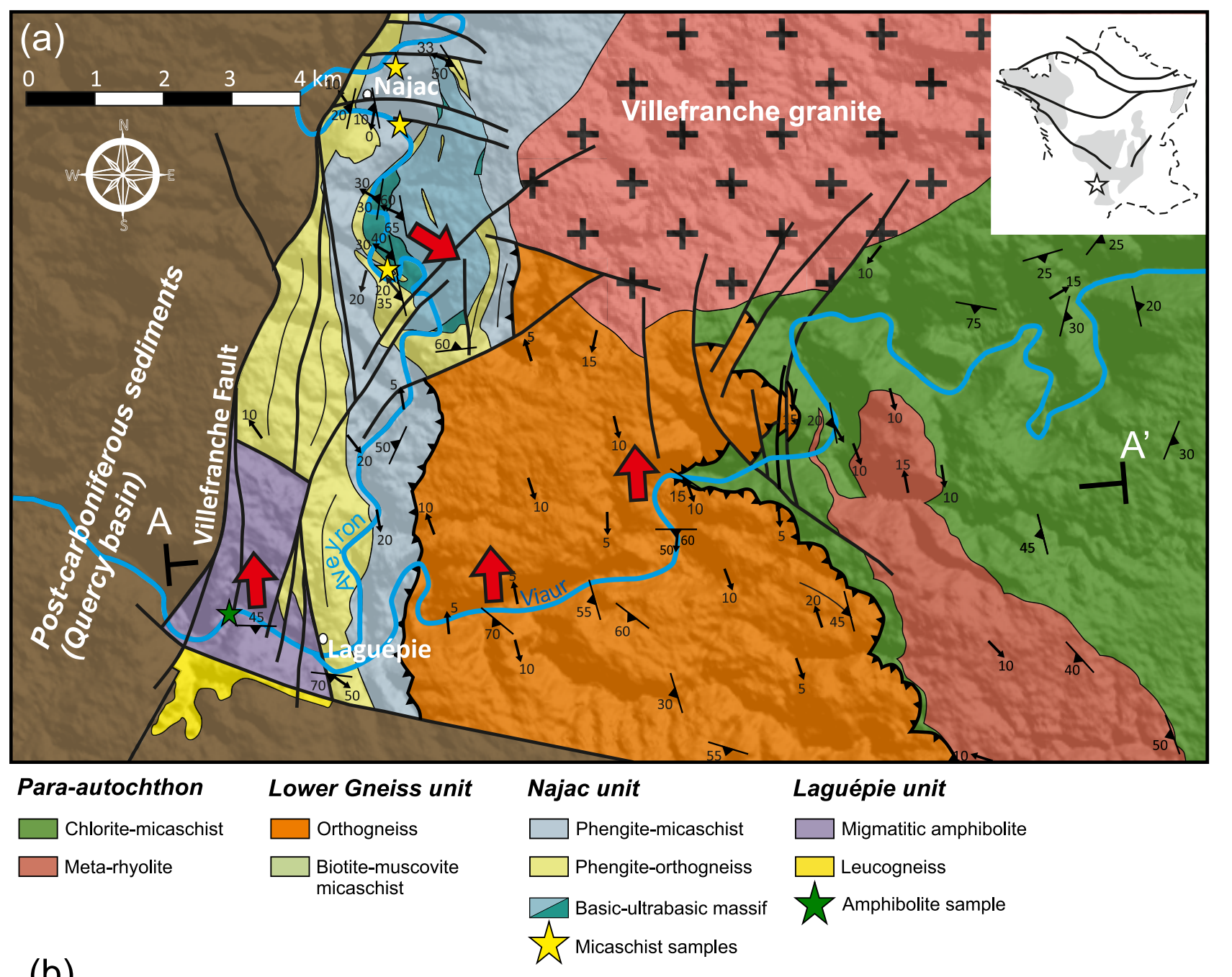

(b) $\begin{array}{cc}\text { Laguépie unit - } & \text { Najac unit - } \\ \text { (amphibolite facies) } & \text { (eclogite facies) }\end{array}$

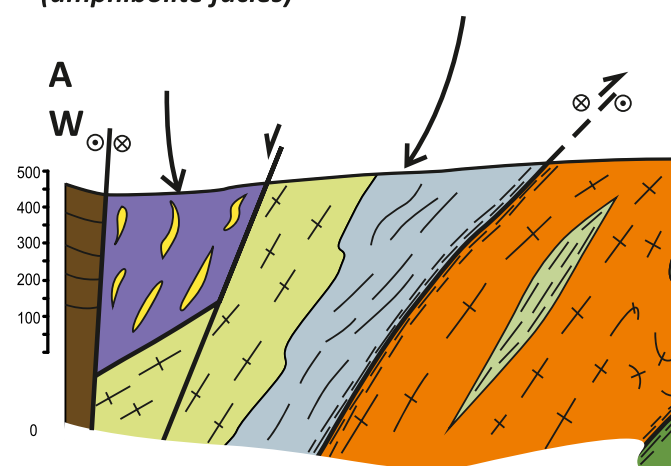

Para-autochthon

(micaschist and orthogneiss, greenschist facies)
Lower Gneiss Unit

(orthogneiss and micaschists, amphibolite facies)

Fig. 1. Geological setting of the Najac and Laguépie units: (a) geological map modified after Burg et al. (1989a). The red arrows indicate the kinematics deduced from $\mathrm{C}$ '/C/S structures; (b) interpretative W-E cross section with indication of lithology and metamorphic facies for each unit. 

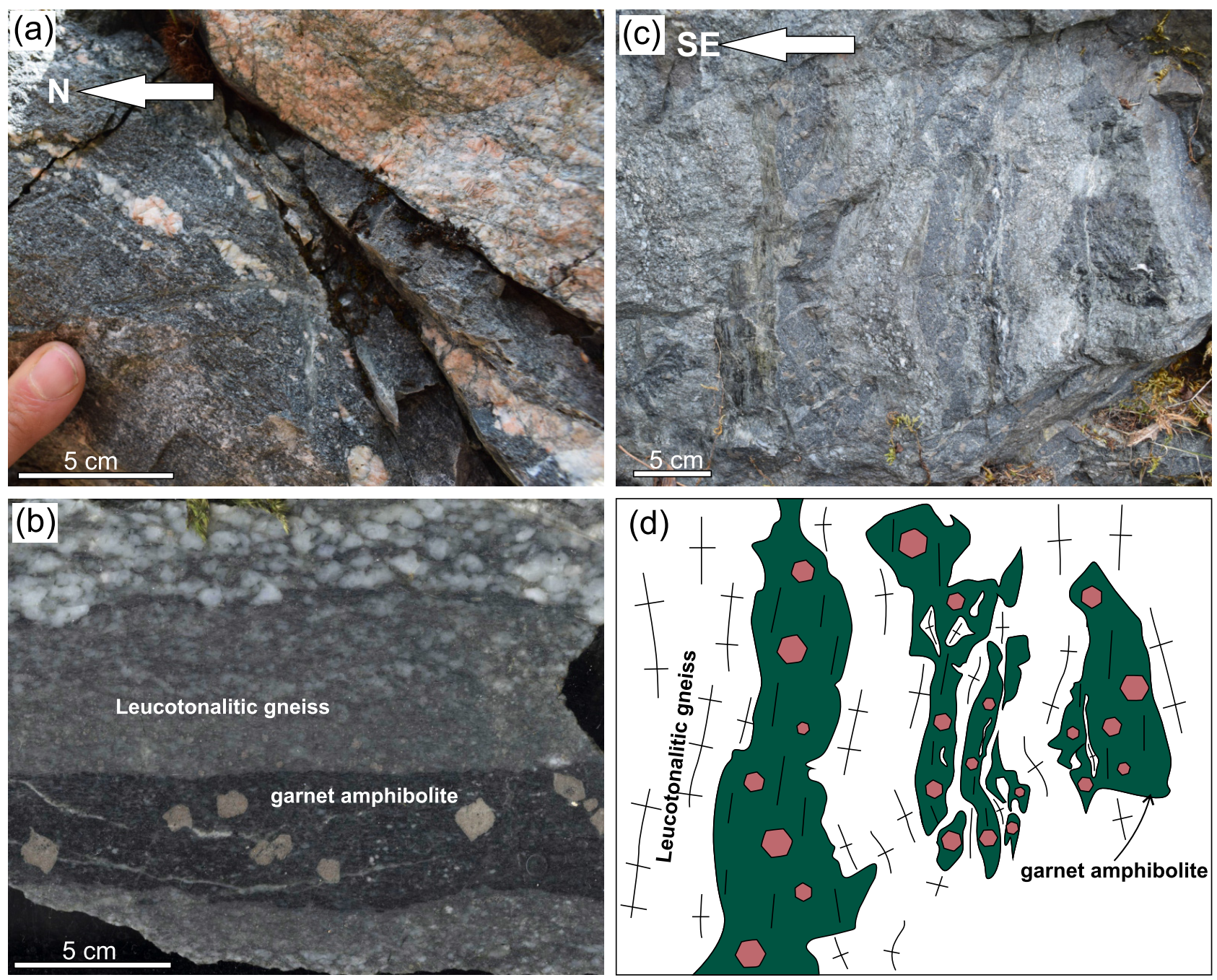

Fig. 2. Main macroscopic features of the Laguépie unit: (a) field photographs of leucotonalitic lenses into garnet-free amphibolite (AJAH9; $\left.1,9558^{\circ} \mathrm{E}, 44,1485^{\circ} \mathrm{N}\right)$; (b) polished section of a garnet amphibolite within a quartz-feldspar-chlorite leucogneiss $\left(\mathrm{AJAH} 8\right.$; $1,9602^{\circ} \mathrm{E}$; $\left.44,1468^{\circ} \mathrm{N}\right)$; (c) outcrop image of the complex relationship between garnet amphibolite lenses and leucotonalitic veins $\left(1,9602^{\circ} \mathrm{E} ; 44,1468^{\circ} \mathrm{N}\right)$. Note the crosscutting relationships and the cauliflower-like structure at the leucogneiss/amphibolite contact; (d) sketch of the outcrop image shown in (c).

granodioritic pluton (Burg et al., 1989b). It is bounded by the Villefranche fault to the west, which separates the metamorphic units from the large Permian to Mesozoic Quercy basin and it is unconformably overlain by Permian and Cenozoic deposits to the south.

\section{Samples description and mineral chemistry}

In order to compare the metamorphic evolution of Najac and Laguépie units, we focus our study on several samples of phengite-garnet micaschists surrounding the basic-ultrabasic complex and on amphibolites and associated leucotonalitic gneisses at Laguépie. The orthogneisses around Najac are deformed but their mineral assemblage did not fully reequilibrate during metamorphism (except for some late kinematic Si-rich white micas); these samples were consequently disregarded in this study.

\subsection{The Laguépie unit}

Samples were collected in an abandoned quarry along the Aveyron valley, west of Saint Martin de Laguépie. The amphibolites are homogeneous amphibole-plagioclase rocks alternating with discontinuous leucotonalitic orthogneisses forming isolated lenses (several millimetres to $20 \mathrm{~cm}$ in width) (Fig. 2a). In the eastern side of the quarry, one outcrop exposes discontinuous and rounded levels of melanocratic garnet amphibolite wrapped into large veins of leucogneiss. Contacts between both lithologies can be either sharp or lobed, occasionally resembling cauliflower structures in migmatites (Burg and Vanderhaeghe, 1993) (Fig. 2b-d). The leucogneiss locally cuts across the melanocratic levels and it can also forms deformed lenses within the amphibolites (Fig. 2c). These observations suggest that the unconnected felsic lenses were formed in situ in the amphibolites while large felsic veins or dykes containing lobed fragments of garnet amphibolites are the 
results of melt drainage and segregation. Accordingly, these field observations suggest that the precursor leucotonalitic magma formed after incipient partial melting of the amphibolite.

The most common lithology of the Laguépie unit is an amphibolite made of amphibole, plagioclase and quartz. Plagioclase is commonly cloudy due to advanced sericitization and frequently contains epidote neoblasts (Fig. 3a, b). Amphibole porphyroclasts are pleiochroic from blue-green to brownish and small needles of light colored green amphibole are found at the contact with plagioclase (Fig. $3 \mathrm{a}, \mathrm{b})$. Quartz is common, but never exceed 10 vol.\%. The texture is porphyroclastic with oblique localized cataclastic shear bands consisting of crushed chlorite, actinolite and albite grains (Fig. 3a). Secondary calcite and pyrite-chlorite veins cut across plagioclase and amphibole with aligned euhedral pyrite crystals is also commonly observed.

Garnet amphibolite levels consist of a mineral assemblage of plagioclase-amphibole-garnet \pm titanite \pm quartz $\pm \mathrm{k}$-feldspar with large (up to $3 \mathrm{~cm}$ width), subrounded, pre-kinematic porphyroclastic garnet rich in quartz inclusions (Fig. 3c). Elongated porphyroclasts of amphibole and plagioclase alternating with rare quartz ribbons define a foliation wrapping the garnet (Fig. 3c). Titanite, apatite, zircon and pyrite are the most common accessory phases. Retrogression is evidenced by the cloudy aspect of plagioclase, the development of lightcolored amphibole needles rimming large brownish porphyroclastic grains, growth of chlorite within fractures cutting across garnet and thin cataclastic shear bands made of chlorite, albite and epidote.

Leucotonalitic gneisses consist of an assemblage of quartzalbite-chloritized biotite $\pm \mathrm{K}$-feldspar \pm garnet and display an augen texture (Fig. 3d) with large porphyroclastic feldspars. Garnet are rounded and small $(<1 \mathrm{~cm})$ compared to those observed the amphibolite layer. Their modal abundance usually decreases from the contact with the amphibolite to the core of the leucocratic orthogneiss vein. Chlorite, probably replacing a former biotite, forms elongated domains aligned along the foliation or $\mathrm{C}-\mathrm{C}$ ' shear bands indicating a top-tothe-north sense of shear.

One amphibolite sample (LAG3b) and one garnetamphibolite sample (AJAH08), collected close to a leucotonalitic vein, were analysed for their mineral composition. The garnet-free amphibolite LAG3b is made of oligoclase $\left(\mathrm{X}_{\mathrm{An}}\right.$ : 0.13-0.17) with albitic rims $\left(\mathrm{X}_{\mathrm{An}}\right.$ : down to 0.07). Amphibole appears as large brown-green crystals characterized by low- $\mathrm{Ti}\left(0.94-1.25 \mathrm{wt} \% \mathrm{TiO}_{2}\right)$ magnesiohornblende $(\mathrm{Mg \#}$ : 54-55, Si: $6.72-6.78$ a.p.f.u., Fig. 4 a) core surrounding Sirich and Ti-poor thin rim (6.84-7.09 Si a.p.f.u.; $0.33-0.69 \mathrm{wt}$ $\% \mathrm{TiO}_{2}$ Fig. $4 \mathrm{a}$ ). Unaltered plagioclase grains in the garnet amphibolite AJAH08 are more calcic $\left(\mathrm{X}_{\mathrm{An}}: 0.30-0.32\right)$ while altered grains are albitic $\left(\mathrm{X}_{\mathrm{An}}: 0.07-0.10\right)$. The amphibole is also a low $\mathrm{Ti}\left(0.73-1.05 \mathrm{wt} \% \mathrm{TiO}_{2}\right)$ tschermakite (Si 6.24-6.41 a.p.f.u., Mg\#: 51-54, Fig. 4a), with thin magnesiohornblende rims ( $\mathrm{Si}$ up to 6.78 a.p.f.u., Fig. 5a). A discrete chemical zoning was evidenced in a large garnet porphyroclast varying from $\mathrm{Alm}_{55}-\mathrm{Spss}_{4} \operatorname{Prp}_{12} \mathrm{Grs}_{29}$ to $\mathrm{Alm}_{58} \mathrm{Spss}_{2} \operatorname{Prp}_{14} \mathrm{Grs}_{25}$ (Fig. 4b). Amphibole inclusions into garnet show the same tschermakitic composition as the ones forming the matrix.

\subsection{Micaschists of the Najac unit}

Micaschists of the Najac units are homogeneous light grayblue rocks displaying a penetrative planar fabric with poorly defined mineral lineation. Granoblastic and elongated quartz and plagioclase form millimeter-scale layers alternating with phengite-rich bands (Fig. 3a). Biotite is present in low volumetric proportions but is preferentially concentrated at the contact between garnet and white mica (Fig. 3e). In most samples, garnet forms minute $(<300 \mu \mathrm{m}$ in diameter $)$ subhedral grains within the phengitic layers and show pressure shadows filled with biotite and phengite (Fig. 3e). Garnet is rich in quartz and rutile inclusions sometimes delineating a foliation that can be parallel or oblique to the main planar fabric. NJC08 contains centimetric syn-kinematic fibrous snowball garnet porphyroblasts with quartz inclusions and enclosed into phengite stacks (Fig. 3f), substantiating that garnet growth occurred during deformation. Accessory minerals consist of rutile (partly transformed into ilmenite), apatite and zircon.

Garnet chemical zoning is obvious in sample NJC11 where compositions range from $\mathrm{Alm}_{41} \mathrm{Spss}_{27} \mathrm{Prp}_{2} \mathrm{Grs}_{30}$ in the core to $\mathrm{Alm}_{66} \mathrm{Spss}_{4} \mathrm{Prp}_{5} \mathrm{Grs}_{25}$ in the rim (Fig. 5b), while its Fe\# decreases from core to rim (96 to 92). Garnet in NJC12a shows a more homogenous composition with core at $\mathrm{Alm}_{68} \mathrm{Spss}_{4} \operatorname{Prp}_{6} \mathrm{Grs}_{22}$ and a rim at $\mathrm{Alm}_{72.5} \mathrm{Spss}_{1.5} \operatorname{Prp}_{7} \mathrm{Grs}_{19}$ at nearly constant $\mathrm{Fe} \#$ (91-93). White micas are phengitic with $\mathrm{Si}$ (per formula unit, on the basis of 11 oxygens) ranging from 3.30 to 3.40 in NJC08, 3.18 to 3.36 in NJC12a and 3.17-3.35 in $\mathrm{NJC11}$; and $\mathrm{Fe}+\mathrm{Mg}$ (a.p.f.u.) between 0.20 and 0.45 . Phengite crystals with the lowest $\mathrm{Si}$ content are found close to biotite and in the rim of large grains. Biotite has generally low $\mathrm{Ti}$ (0.09-0.11 a.p.f.u) with Mg\# varying from 0.45 and 0.50 and low Si (2.70-2.80 a.p.f.u.) in the three analyzed samples. Plagioclase is an oligoclase with $\mathrm{X}_{\mathrm{An}}$ comprised between $0.14-0.16$ in NJC11 and NJC12a.

\section{Pressure-temperature estimations}

\subsection{Amphibolites from the Laguépie unit}

Garnet amphibolite AJAH08 collected in the outcrop shown in Figure 2c, d was selected for detailed thermobarometric investigations because it contains garnet, a good tracer to recover P-T conditions. The sample's bulk composition has been calculated using modal proportions (estimated by pixel counting on thin section images) and core composition of unaltered rock forming minerals (garnet, amphibole, plagioclase, titanite and quartz). Two different estimations were made and the results were differing by less than $5 \%$ (relative) on the different oxides proportions. Phase diagrams were calculated with Perple_X (Connolly, 2009) in the system $\mathrm{Na}_{2} \mathrm{O}-\mathrm{CaO}-\mathrm{FeO}-\mathrm{MnO}-\mathrm{MgO}-\mathrm{TiO}_{2}-\mathrm{Al}_{2} \mathrm{O}_{3}-\mathrm{SiO}_{2}-\mathrm{H}_{2} \mathrm{O}$. Water content has been estimated on the basis of the modal proportion of amphiboles, considering they contain approximately $2 \mathrm{wt} \% \mathrm{H}_{2} \mathrm{O}$. The calculation uses the thermodynamic database of Holland and Powell (2011, update ds62) and solid solution models adapted for amphibolite to granulite facies mafic rocks (see Green et al., 2016). Ferric iron was not considered because its content in minerals (estimated by stoichiometry) is very low and no oxides containing ferric iron 

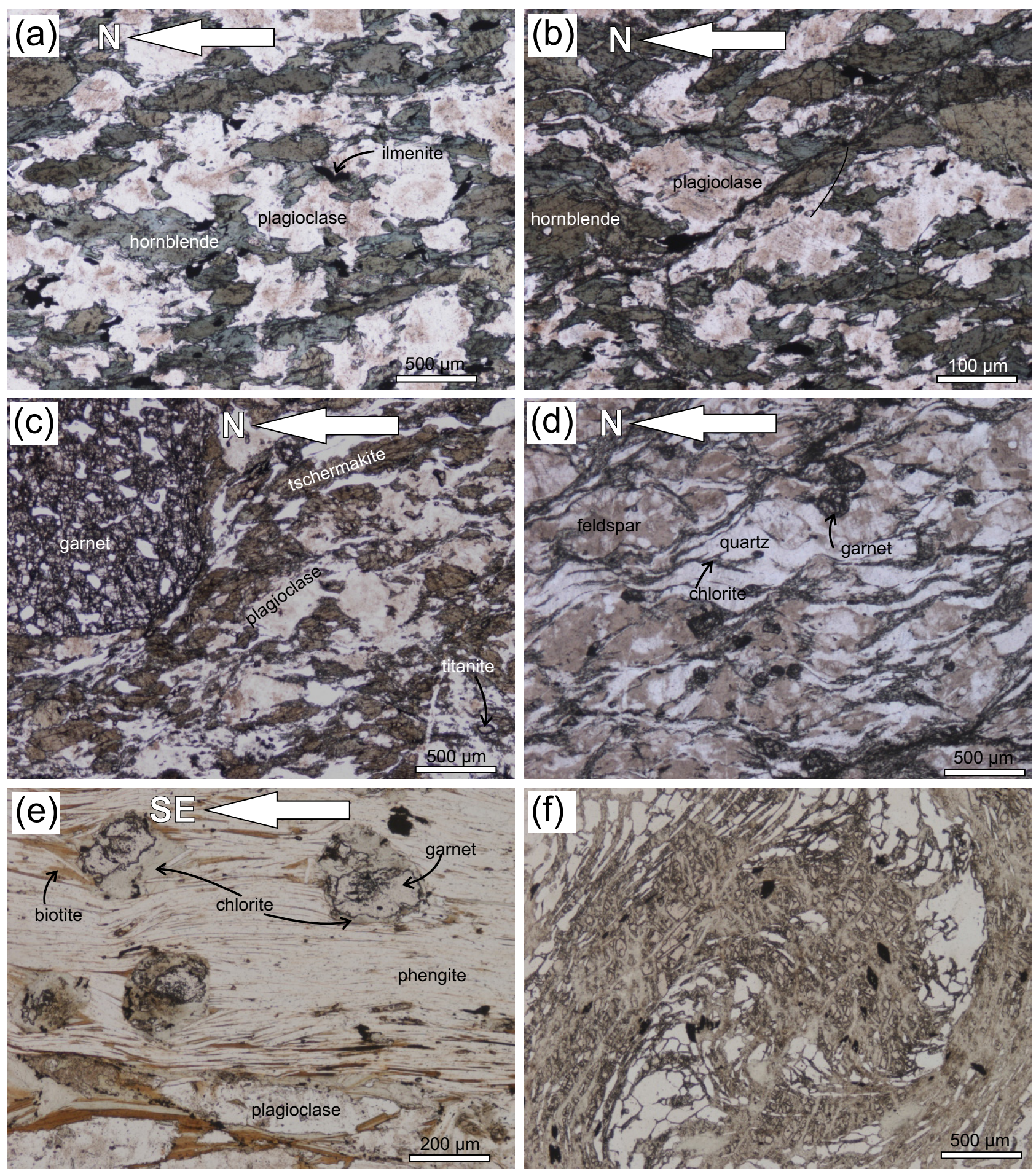

Fig. 3. Photomicrographs of representative samples from the Najac and Laguépie units. Laguépie samples: (a) amphibole-plagioclase-ilmenite amphibolite LAG3b representing the dominant lithology of the Laguépie amphibolite $\left(1,9558^{\circ} \mathrm{E}, 44,1485^{\circ} \mathrm{N}\right)$; (b) chlorite-epidote-albite shear band oblique to the main foliation and indicating a top to the north sense of shear (sample LAG3b); (c) garnet amphibolite AJAH08 with foliation molded around the garnet porphyroclast; (d) leucogneiss from sample AJAH08 showing a porphyroclastic augen texture. Note the C/S structure marked by chlorite formed after soldification and cooling of the leucotonalitic orthogneiss; (e) Representative texture of the Najac unit garnetphengite micaschists (sample $\mathrm{NJC} 12 \mathrm{a} ; 1.9754^{\circ} \mathrm{E}, 44,2159^{\circ} \mathrm{N}$ ). Note the pressure shadows filled with biotite and phengite around garnet indicating that the high pressure assemblage is syn-kinematic. Greenish chlorite partly replaces garnet and biotite in all samples; (f) large porphyroclastic snowball and skeletal garnet from sample $\mathrm{NJC} 11\left(1,9693^{\circ} \mathrm{E} ; 44,2196^{\circ} \mathrm{N}\right)$, again showing that the high-pressure mineral assemblage developed during deformation. 
(a)

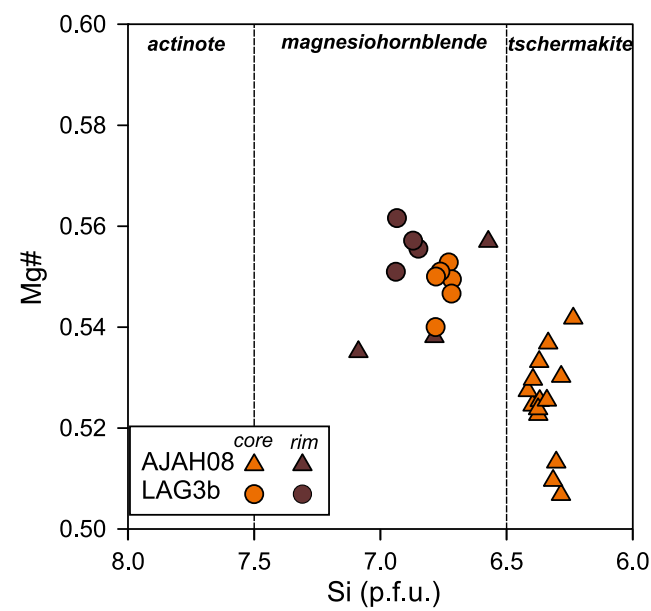

(b)

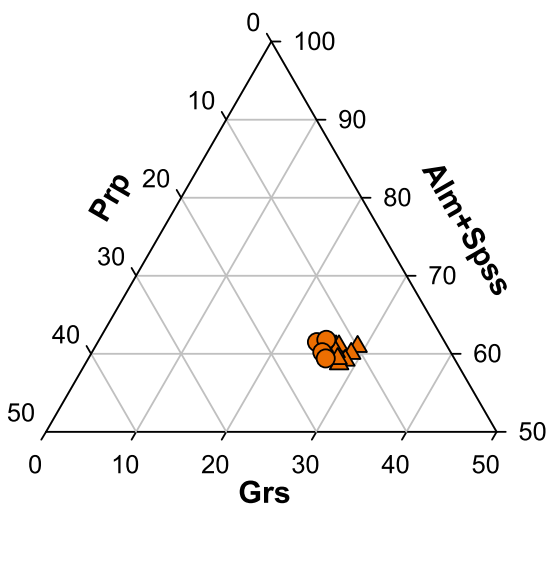

Fig. 4. Minerals compositions in the amphibolites from the Laguépie unit: (a) amphibole composition in the classification diagram by Leake et al. (1997); (b) garnet compositions in AJAH08.

(a)

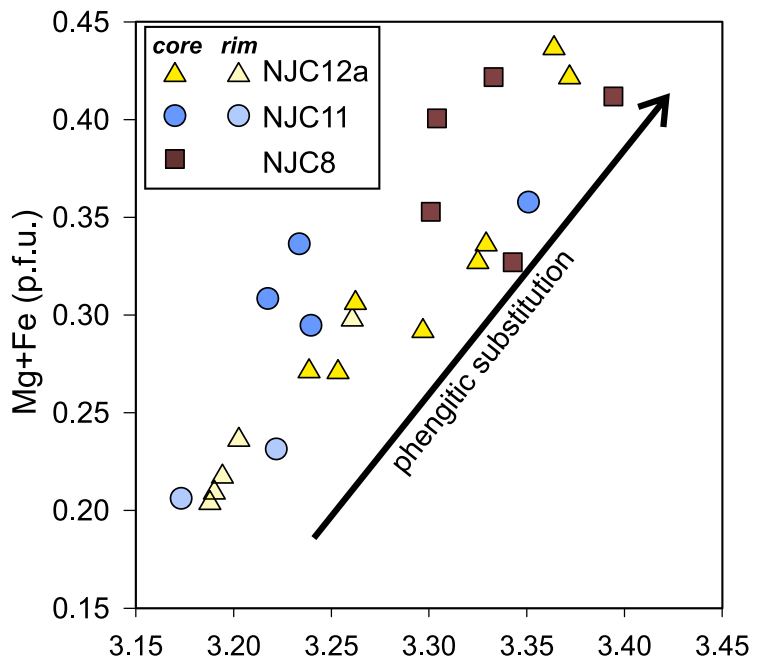

(c)

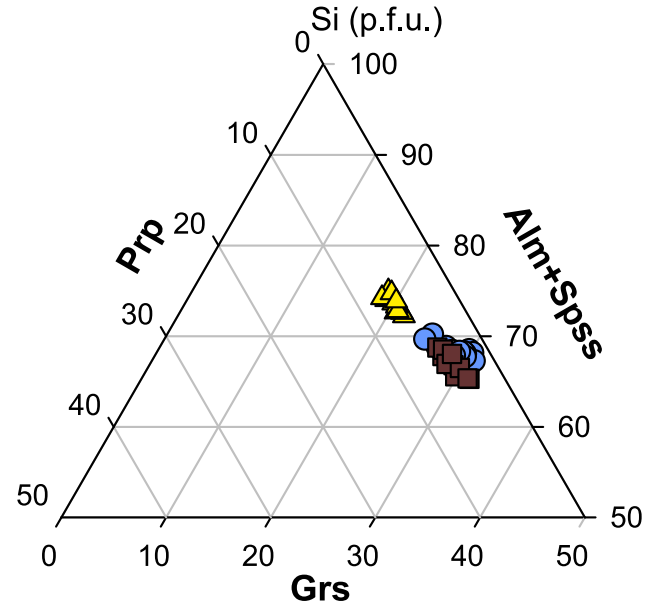

(b)

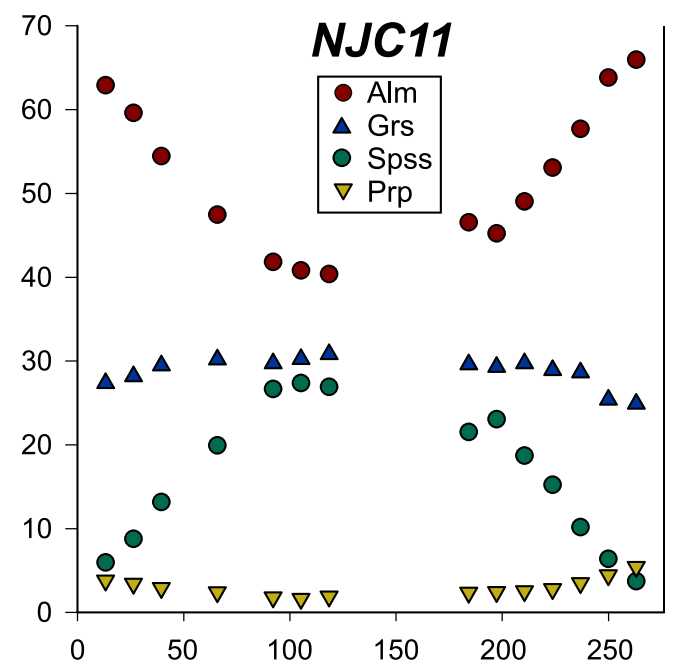

Fig. 5. Minerals composition in the micaschists from the Najac unit: (a) Si versus $\mathrm{Fe}+\mathrm{Mg}$ diagram for white micas showing the phengitic substitution; (b) garnet zoning profile in $\mathrm{NJC11}$; (c) garnet composition for three representative samples (NJC8, NJC11 and NJC12a). 
$\begin{array}{lllllllll}\mathrm{Na}_{2} \mathrm{O} & \mathrm{MgO} & \mathrm{Al}_{2} \mathrm{O}_{3} & \mathrm{SiO}_{2} & \mathrm{CaO} & \mathrm{TiO}_{2} & \mathrm{FeO} & \mathrm{MnO} & \mathrm{H}_{2} \mathrm{O}\end{array}$

$\begin{array}{lllllllll}3.76 & 4.30 & 17.69 & 54.22 & 8.90 & 1.12 & 8.36 & 0.18 & 0.84\end{array}$

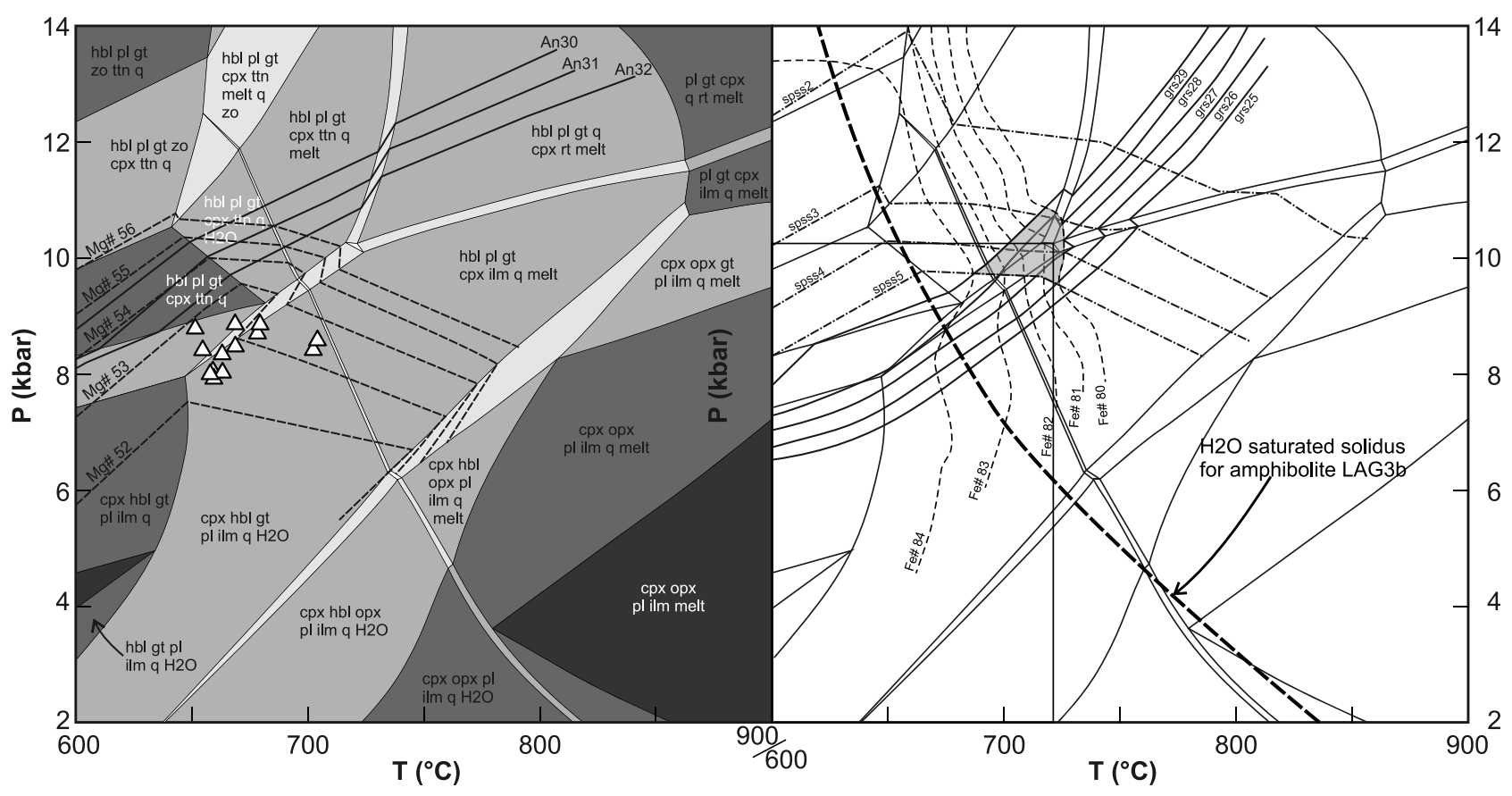

Fig. 6. Isochemical phase diagram built for the bulk composition of the garnet amphibolite in sample AJAH08 of the Laguépie unit: (a) phase diagram also showing the isopleth for XAn in plagioclase and $\mathrm{Mg \#}$ of amphibole (corresponding to composition determined with the electron microprobe). The small triangles represent the results of garnet-amphibole plagioclase-quartz thermobarometry; (b) Fe\#, grossular and spessartine isopleths in garnet corresponding to composition measured by electron microprobe. Also shown is the vapor-saturated solidus for the amphibolite LAG3b.

were observed. The mineral assemblage observed in the garnet amphibolite AJAH08 (plagioclase-amphibole-garnet \pm titanite \pm quartz) cannot be reproduced in the isochemical phase diagram because the calculation systematically predicts the presence of small amounts $(<4 \mathrm{vol} . \%)$ of clinopyroxene in fields where amphibole, garnet and plagioclase are stable. This can be a consequence of retrograde metamorphism that has transformed clinopyroxene into amphibole or inaccuracies of the calculated model. Garnet, plagioclase, amphibole, quartz and titanite without orthopyroxene, epidote, ilmenite or rutile coexist between 8 and $14 \mathrm{kbar}$ and 600 and $740{ }^{\circ} \mathrm{C}$ (Fig. 6). $\mathrm{X}_{\mathrm{An}}$ and $\mathrm{Mg \#}$ isopleths for plagioclase and amphibole, respectively, cross between 8 and $10 \mathrm{kbar}$ at $600-700{ }^{\circ} \mathrm{C}$ in fields where low amounts of clinopyroxene are predicted ( $<4$ vol.\%) (Fig. 6). The overlapping zone of various garnet isopleths (Fe\#, grossular, spessartine contents) yields P-T conditions of $710 \pm 15^{\circ} \mathrm{C}$ and $10 \pm 1 \mathrm{kbar}$ (Fig. 6). As the garnet cores display higher Fe\# (up to 84) and grossular content (up to $29 \mathrm{~mol} \%$ ) compared to the rim (Fe\# down to 80 and 26 grossular mol\%), the slight zoning observed in garnet could trace a small increase in temperature from 690 to $730{ }^{\circ} \mathrm{C}$ at nearly constant pressure (Fig. 6). This P-T domain locates close to the ilmenite-titanite and ilmenite-rutile phase transitions but also clinopyroxene ( $<4$ vol.\%) and melt present $(<2$ vol.\%) fields (Fig. 6); consequently, it lies above the vapor-present solidus calculated for the amphibole-plagioclase-ilmenite amphibolite LAG3b. It is worth to note that the calculated phase diagram closely reproduces the observed modal proportion of garnet $(7 \mathrm{vol} . \%)$ around $700{ }^{\circ} \mathrm{C}$ and $10 \mathrm{kbar}$.

Application of garnet-amphibole-plagioclase-quartz barometry (Kohn and Spear, 1990) with hornblende-plagioclase thermometry (Holland and Blundy, 1994) yields 640 $700{ }^{\circ} \mathrm{C}, 8-9 \mathrm{kbar}$. LAG3b plagioclase amphibole pairs yield similar albeit slightly lower temperature conditions of 640 $680^{\circ} \mathrm{C}$ at a fixed pressure of $9 \mathrm{kbar}$. The magnesiohornblende and albitic rims in AJAH08 equilibrated at lower temperature $\left(480-560^{\circ} \mathrm{C}\right)$.

\subsection{Micaschists from the Najac unit}

Sample NJC11 and NJC12a were selected for isochemical phase diagram calculations. They were calculated in the system $\mathrm{Na}_{2} \mathrm{O}-\mathrm{K}_{2} \mathrm{O}-\mathrm{FeO}-\mathrm{MnO}-\mathrm{MgO}-\mathrm{TiO}_{2}-\mathrm{Al}_{2} \mathrm{O}_{3}-\mathrm{SiO}_{2}-\mathrm{H}_{2} \mathrm{O}$ using the Holland and Powell (1998) thermodynamic database revised in 2002, with solid solution models from Tajcmanova et al. (2009) for biotite, Newton et al. (1980) for plagioclase, Holland and Powell (1998) for garnet, Coggon and Holland (2002) for white mica, Holland and Powell (1998) for chlorite. We ignored ferric iron because calculated $\mathrm{Fe}^{3+}$ in silicates (by charge balance or stoichiometry) is systematically very low and $\mathrm{Fe}^{3+}$ bearing oxides are absent. Before drawing the isochemical section using the bulk rock composition measured by XRF spectrometry (CAF service, Stellenbosch University, South Africa), we tested different bulk water content using T-X sections because calculated pyrope content in garnet is 

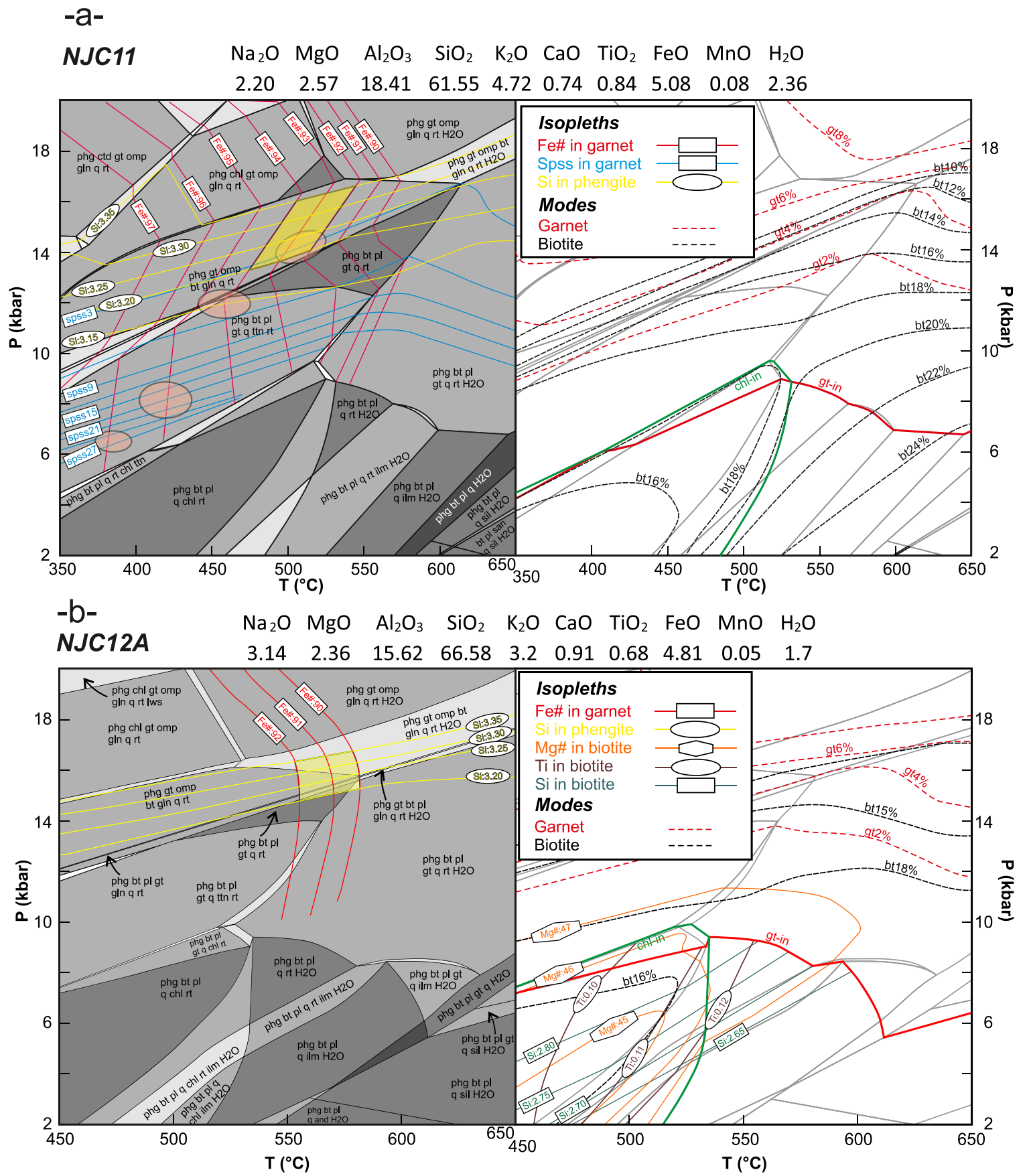

Fig. 7. Isochemical phase diagrams computed for compositions corresponding to garnet micaschists from the Najac unit: (a) sample NJC11 used to determine the prograde P-T path; (b) sample NJC12a used to determine the peak P-T conditions and the retrograde path. Garnet in/out and chlorite in/out curves are indicated in bold to better localize the retrogression in greenschist facies conditions.

extremely sensitive to bulk rock $\mathrm{H}_{2} \mathrm{O}$ content. The best results, i.e. convergence of garnet isopleths and reproduction of the observed mineral assemblages, were obtained with the $\mathrm{H}_{2} \mathrm{O}$ content calculated using the micas modal proportion and considering a $\mathrm{H}_{2} \mathrm{O}$ content of $\sim 5 \mathrm{wt} \%$ in white mica.

Garnet in NJC11 preserved a well-developed bell shaped Mn profile. Core composition (spss: $27 \mathrm{~mol} \%$ and Fe\#: 96) are in equilibrium in greenschist facies conditions $\left(360-400^{\circ} \mathrm{C}, 6-\right.$ $7 \mathrm{kbar})$ slightly above the garnet-in phase boundary in a field where muscovite, biotite, plagioclase, garnet, titanite and rutile are in equilibrium (Fig. 7a). Intermediate compositions between core and rim draw a linear prograd path passing at $420^{\circ} \mathrm{C} / 8 \mathrm{kbar}$ and $460{ }^{\circ} \mathrm{C} / 12 \mathrm{kbar}$. Garnet rims equilibrated at $510 \pm 20^{\circ} \mathrm{C}$ and $14 \pm 1 \mathrm{kbar}$ in a field where phengitic mica, biotite, plagioclase, garnet, quartz and rutile are stable with minor amounts of sodic amphibole and clinopyroxene (Fig. 7a). Computed modal proportion for garnet and biotite are low ( $<6 \mathrm{vol} . \%$ and $<10 \mathrm{vol} . \%$, respectively). Isopleths of $\mathrm{Si}$ content in phengite (3.20-3.35 p.f.u.) and of $\mathrm{Fe \#}$ in garnet (93-94) cross at $510 \pm 30^{\circ} \mathrm{C}$ and $15 \pm 2$ kbar. 
The field corresponding to the high-pressure assemblage observed in NJC12a (phengite-quartz-biotite-garnet-plagioclase-rutile) lies within $500-570^{\circ} \mathrm{C}$ and $13-16 \mathrm{kbar}$ under vapor under-saturated conditions (Fig. 7b). Free $\mathrm{H}_{2} \mathrm{O}$ coexist with the observed assemblage at higher temperatures. At higher pressure conditions, the formation of sodic amphibole and pyroxene appears as a result of plagioclase and biotite breakdown while titanite is stable below 13-14 kbar and 520$560^{\circ} \mathrm{C}$ (Fig. $7 \mathrm{~b}$ ). Calculated $\mathrm{Fe} \#$ in garnet is temperature sensitive. Measured values (90-92) correspond to temperatures ranging between 520 and $585^{\circ} \mathrm{C}$ for 10 and $20 \mathrm{kbar}$ of pressure (Fig. 7b). These isopleths cross those representing measured $\mathrm{Si}$ content in white mica $(3.18-3.36$ a.p.f.u.) in a narrow P-T domain centered at $570 \pm 15^{\circ} \mathrm{C}$ and $16 \pm 1 \mathrm{kbar}$ (Fig. 7b). Our calculation predicts minor amounts of sodic pyroxene and amphibole ( $<10$ vol.\%), despite these ones were not observed in any micaschist samples. It can be due to retrogression of these phase or to inaccuracies of the thermodynamic calculations. Calculated grossular content in this P-T domain $(0.20-0.28$, increasing with decreasing pressure) is slightly above those determined with electronmicroprobe $(0.18-0.22)$. The pressure conditions at which measured and calculated grossular content are overlapping $(0.20-0.22)$ are around $17 \mathrm{kbar}$. Low-Si $(2.72-2.78$ a.p.f.u.) biotite with $\mathrm{Mg} \#$ of $45-48$ and Ti between 0.10 and 0.11 p.f.u. is in equilibrium between $460-520^{\circ} \mathrm{C}$ and $2-7 \mathrm{kbar}$ (Fig. 7b); this is consistent with the presence of chlorite in the retrograde assemblage and the higher modal amounts of biotite calculated in greenschist facies conditions (around 16 vol.\%) compared to eclogitic conditions ( $<10$ vol.\%). Biotite stable in the eclogite facies has much higher calculated Si content ( $>2.90$ a.p.f.u.), compositions that were not observed in our samples.

\section{Zircon U-Pb geochronology}

The age of high-pressure, low temperature metamorphism in the Najac eclogite has been recently determined by multimethod geochronology (prograde path at 385-383 Ma, HP peak at $377 \pm 3 \mathrm{Ma}$, exhumation around $369 \pm 13 \mathrm{Ma}$; Sm-Nd and $\mathrm{Lu}-\mathrm{Hf}$ isochron plus $\mathrm{U}-\mathrm{Pb}$ zircon and apatite dating by Lotout et al., 2018) but the age of amphibolite facies metamorphism in the Laguépie amphibolite has not been constrained. A large leucotonalitic lens (AJAH09, $20 \times 30 \mathrm{~cm}$ ) included into the amphibolite was sampled, from which about 40 zircon grains were extracted using heavy liquids and magnetic separation techniques at the Geosciences Environnement Toulouse laboratory.

Zircon images were acquired using a cold-cathode optical cathodoluminescence (CL) at the University of Mons using a Cambridge Image Technology model $8200 \mathrm{Mk} 5$ system. They are generally small (length $<200 \mu \mathrm{m}$ ), with minute quartz and apatite inclusions. These zircons show two different textures (Fig. 8a):

- cores of subhedral elongated grains or crystal fragments with dark shade (CL or transmitted light) displaying chaotic or no zoning and being often cracked with fractures extending into the rims. These features are typical of metamict zircons (Corfu et al., 2003);
- luminescent part, often light brown and translucent, riming the dark cores and showing oscillatory growth zoning. These rims are usually 15 to $50 \mu \mathrm{m}$ large and are relatively rare compared to dark zircon cores. These luminescent rims were also found as isolated fragments.

U-Pb analyses were performed at Géosciences Montpellier (University of Montpellier, France) using a Teledyne G2 excimer laser probe coupled to a ThermoFinnigan Element XR high-resolution ICP-MS (AETE-ISO regional facility of the OSU OREME). The probe was set at $25 \mu \mathrm{m}$ diameter, with an ablation frequency of $4 \mathrm{~Hz}$ and a fluency of $6 \mathrm{~J} / \mathrm{cm}^{2}$. More details on analytical setup can be found in Bosch et al. (2011). Unknowns were calibrated against zircon 91500 standard reference material and GJ-1 was used as secondary standard (both reference materials were analyzed before and after each 5 unknowns). U-Pb ages and common $\mathrm{Pb}$ corrections were calculated using the IsoplotR code by Vermeesch (2018). Twelve analyses of GJ-1 zircon yield an upper intercept of $605 \pm 14 \mathrm{Ma}$ with $606 \pm 7 \mathrm{Ma}$ and $598 \pm 5 \mathrm{Ma}$ for the average ${ }^{207} \mathrm{~Pb} /{ }^{235} \mathrm{U}$ and ${ }^{206} \mathrm{~Pb} /{ }^{238} \mathrm{U}$ ages, respectively. This is in good agreement with the recommended values, i.e. an upper intercept of $608.5 \pm 1.5 \mathrm{Ma}$ calculated from slightly discordant ID-TIMS analyses (Jackson et al., 2004).

Dark metamict cores are U-rich (often $>1000 \mathrm{ppm}$ and up to $4650 \mathrm{ppm}$ ) and yield strongly discordant U-Pb ellipses (Fig. 8 b; Tab. 1). The ablation spectra were moreover irregular and consequently, none of the analyzed zircon cores were used to calculate an age. About 15 spots were shot in the luminescent zoned rims but only 9 were not contaminated by the U-rich metamict cores or by apatite inclusions in depth (evidenced by irregular ablation spectra and/or a continuous increase in $\mathrm{U}$ or $\mathrm{Pb}$ count rates). These analyses show regular ablation spectra for the ${ }^{206} \mathrm{~Pb} /{ }^{238} \mathrm{U}$ ratios (i.e. comparable to those of reference zircons 91500 and GJ-1) but more irregular ones for those involving ${ }^{207} \mathrm{~Pb}$. U contents range between 420 and $1044 \mathrm{ppm}$ and $\mathrm{Th} / \mathrm{U}$ ratios (Tab. 1$)$ are on average slightly higher $(0.02-$ $0.04)$ compared to cores $(\mathrm{Th} / \mathrm{U}: 0.01-0.02$ with one analysis at 0.04 ). The data are discordant (1 to $14 \%$ of discordance, 4 ellipses are overlapping Concordia) with ${ }^{206} \mathrm{~Pb} /{ }^{238} \mathrm{U}$ ages ranging between $356 \pm 9 \mathrm{Ma}$ and $374 \pm 9 \mathrm{Ma}$ and ${ }^{207} \mathrm{~Pb} /{ }^{235} \mathrm{U}$ ages between $370 \pm 12 \mathrm{Ma}$ and $419 \pm 14 \mathrm{Ma}$. Age calculation using a discordia regression line for rim analyzes yields a lower intercept at $363 \pm 3 \mathrm{Ma}(\mathrm{MSWD}=2)($ Fig. 8c). The weighted average of ${ }^{206} \mathrm{~Pb} /{ }^{238} \mathrm{U}$ common $\mathrm{Pb}$ corrected age is slightly older at $365 \pm 3 \mathrm{Ma}$ (Fig. 8d; Tab. 1).

\section{Discussion}

\subsection{Two distinct tectono-metamorphic units with contrasted P-T paths}

The Najac and Laguépie units are grouped into a single tectono-metamorphic unit by different authors (Burg et al., 1984, 1989; Lardeaux, 2014; Faure et al., 2017; Lotout et al., 2018) but we show hereafter that they display different metamorphic histories and ages.

The Najac unit encompasses the eclogitic basic-ultrabasic massif, the phengite-bearing orthogneiss and the phengitegarnet micaschists (Fig. 1). Micaschists record early garnet 
(a)

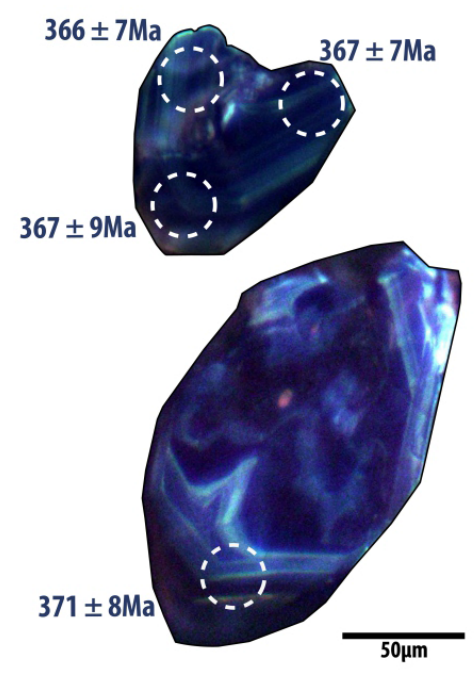

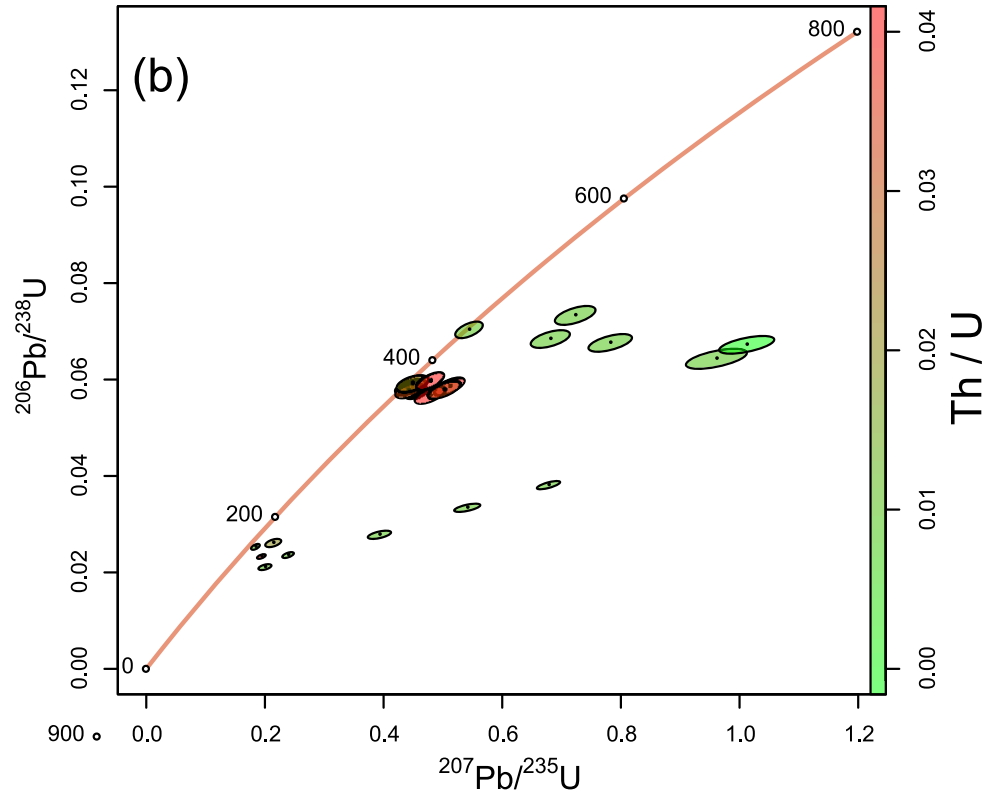

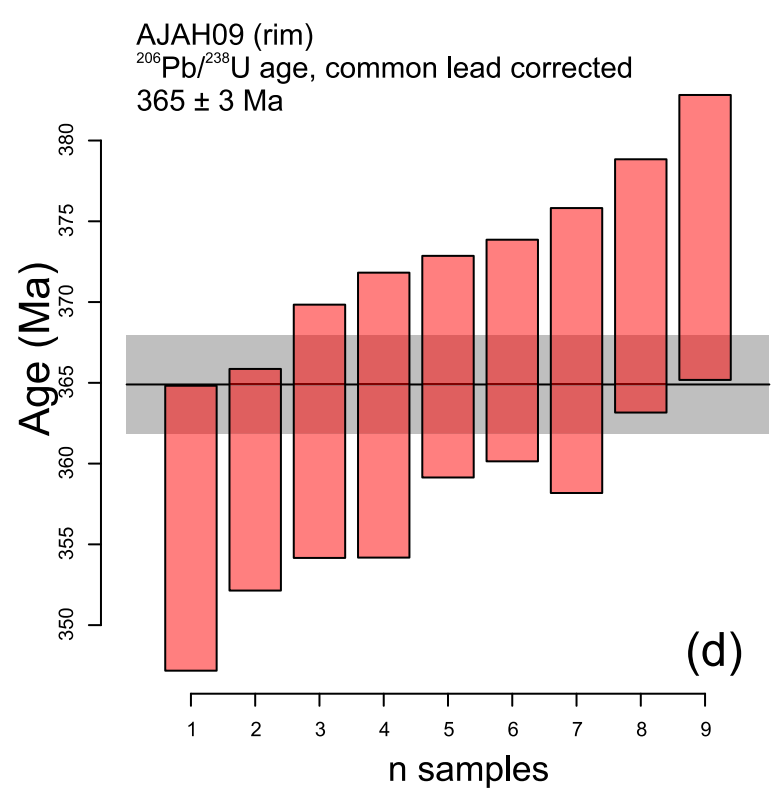

Fig. 8. Results of U-Pb zircon dating for leucogneiss AJAH09 of the Laguépie unit: (a) CL images showing the texture of zircon with dark resorbed metamict cores and luminescent oscillatory zoned rims. Some representative spots made on rims are indicated with their ${ }^{206} \mathrm{~Pb} /{ }^{238} \mathrm{U}$ age; (b) Concordia diagram showing all the U-Pb analyses. Color range corresponds to $\mathrm{Th} / \mathrm{U}$ ratio values. The rim data are the sub-concordant ellipses just below $400 \mathrm{Ma}$; (c) regression of rim $\mathrm{U}-\mathrm{Pb}$ data in a Tera-Wasserburg plot; (d) weighted average of ${ }^{206} \mathrm{~Pb} /{ }^{238} \mathrm{U}$ common lead corrected ages obtained in zircon rims.

nucleation around $360-400{ }^{\circ} \mathrm{C}, 6-7 \mathrm{kbar}$ (Fig. 7a) followed by syn-kinematic growth (Fig. 7a) and equilibration of garnet rims and phengite around $510-570{ }^{\circ} \mathrm{C}$ and $14-17 \mathrm{kbar}$ $\left(\sim 340^{\circ} \mathrm{C} / \mathrm{GPa}\right)$ in the eclogite facies (Fig. $\left.7 \mathrm{a}, \mathrm{b}\right)$. Late- to post-kinematic biotite and chlorite developed preferentially around garnet (Fig. 7b) and are indicative of retrogression in the greenschist facies at $460-520^{\circ} \mathrm{C}$ and $2-7 \mathrm{kbar}$ (Fig. 7b). Lotout et al. (2018) obtained slightly higher peak conditions for an eclogite from the basic-ultrabasic Najac massif $\left(600{ }^{\circ} \mathrm{C}, 18 \mathrm{kbar}\right.$; Fig. 9) but similar thermal gradient at peak pressure $\left(330^{\circ} \mathrm{C} / \mathrm{GPa}\right)$ (Fig. 9). Multi-methods dating performed by Lotout et al. (2018) on an eclogite from Najac constrained the age of prograde evolution around $383-385 \pm 3 \mathrm{Ma}$ and the pressure peak at $377 \pm 3 \mathrm{Ma}$ (Fig. 9). The P-T path determined for the Najac unit (Fig. 9) is different than those determined for the paragneisses and micaschists of the Lower Gneiss and Upper Gneiss units in Limousin and French Massif central (Bellot and Roig, 2007; Faure et al., 2009; Lardeaux, 2014; Do Couto et al., 2016), both showing pervasive recrystallization in the amphibolite facies $\left(600-700^{\circ} \mathrm{C}, 5-10 \mathrm{kbar}\right)$ during Devonian D1 and D2 events (Faure et al., 2009). 
Table 1. Results of U-Pb zircon dating on leucogneiss sample AJAH09.

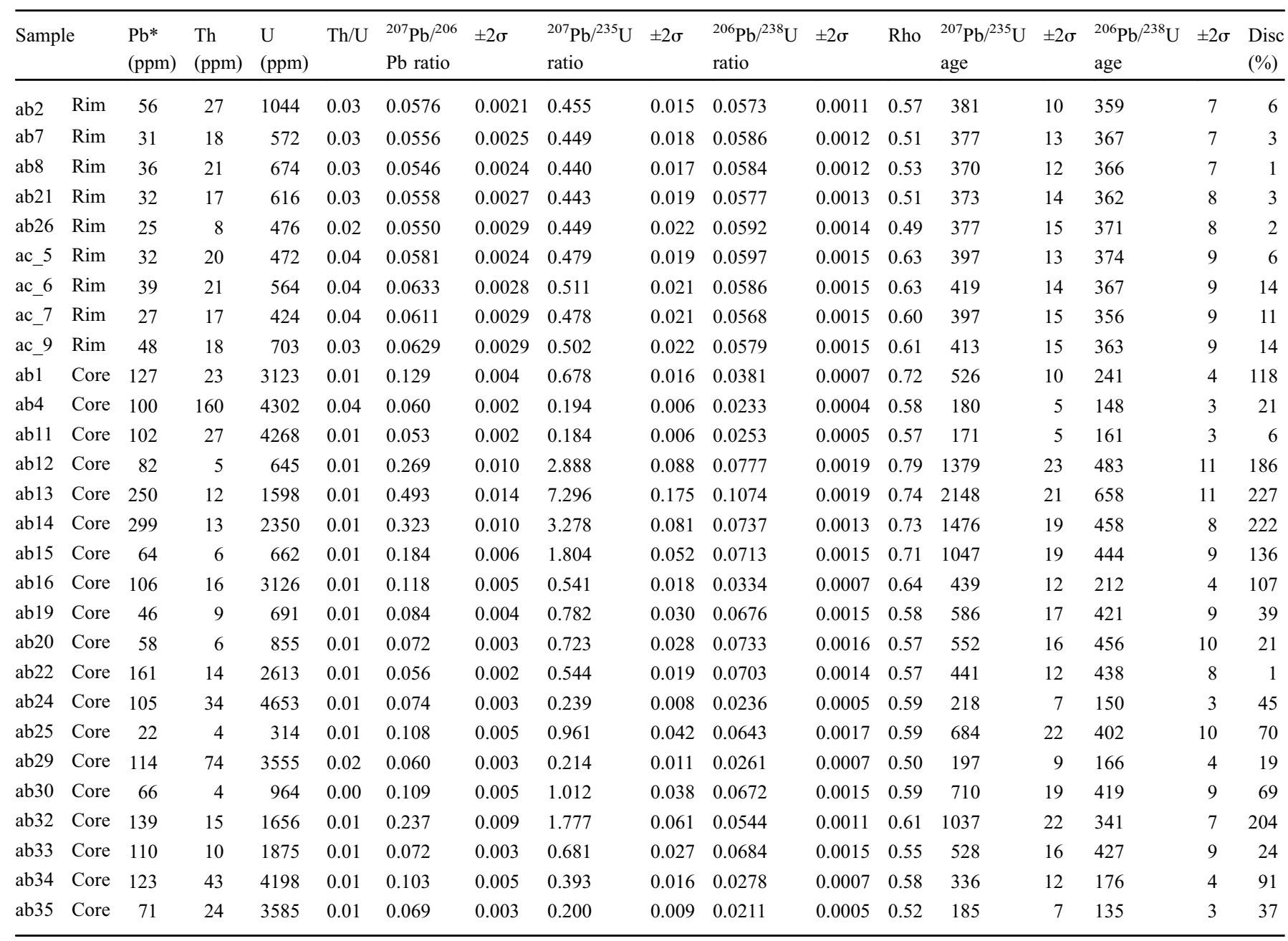

The Laguépie unit comprises garnet-bearing amphibolite, garnet-free amphibolite and a leucotonalitic orthogneiss forming isolated lenses and, sporadically, veins and dykes within amphibolites (Fig. 2). The isolated, unconnected leucotonalitic lenses, the lobed contact between the garnet amphibolite and the leucotonalite magma as well as the sodic nature of the felsic material support that it formed after partial melting of the amphibolite. Garnet in the amphibolite sample AJAH08 preserves core to rim zoning attesting for isobaric ( $\sim 10$ kbar) heating from 690 to $730^{\circ} \mathrm{C}$ (Fig. 6). The main plagioclase-garnet-amphibole-quartz-ilmenite-melt assemblage equilibrated around $700-730^{\circ} \mathrm{C}$ at $10 \pm 1 \mathrm{kbar}$. $\left(\sim 720^{\circ} \mathrm{C} / \mathrm{GPa} ; \sim 20^{\circ} \mathrm{C} / \mathrm{km}\right)$ on a garnet-amphibolite residue. These conditions are just above the vapor-present solidus calculated for the bulk composition of garnet-bearing and garnet-free amphibolites from Laguépie. Retrogression is evidenced by the development of low-Al magnesiohornblende rims around tschermakite in equilibrium with oligoclase and epidote $\left(\mathrm{T}_{\mathrm{Hbl}-\mathrm{Pl}}\right.$ around $\left.510-580^{\circ} \mathrm{C}\right)$ in the epidote-amphibolite and/or greenschist facies. The porphyroclastic texture of garnet, amphibole and plagioclase and the crystallization of albite, chlorite and actinolite whithin cataclasic shear zones were acquired in the amphibolite and greenschist facies, respectively. Solid state deformation characterized by a top-tothe-north sense of shear (the D2 event of Faure et al., 2009) affected the Laguépie unit during retrogression in P-T conditions corresponding to the amphibolite and greenschist facies after the partial melting event. U-Pb ages of luminescent and zoned zircon rims in a leucotonalitic lens from Laguépie unit (sample AJAH09) yield an age of $363 \pm 3 \mathrm{Ma}$ (Fig. 8; Tab. 1) which is interpreted as the timing of felsic magma crystallization following partial melting of the amphibolite.

Our petrological and chronological study demonstrates that these two units have contrasted pressure-temperature-timedeformation histories (Fig. 9) and cannot be assigned to a single tectono-metamorphic unit. The implications of this result are discussed below.

\subsection{Correlations with tectono-metamorphic units of the Western European variscan belt}

The metamorphic units of the FMC are characterized by contrasted P-T evolutions. The metapelites of the paraautochthon have a metamorphic evolution within the greenschist facies locally reaching amphibolite facies near 


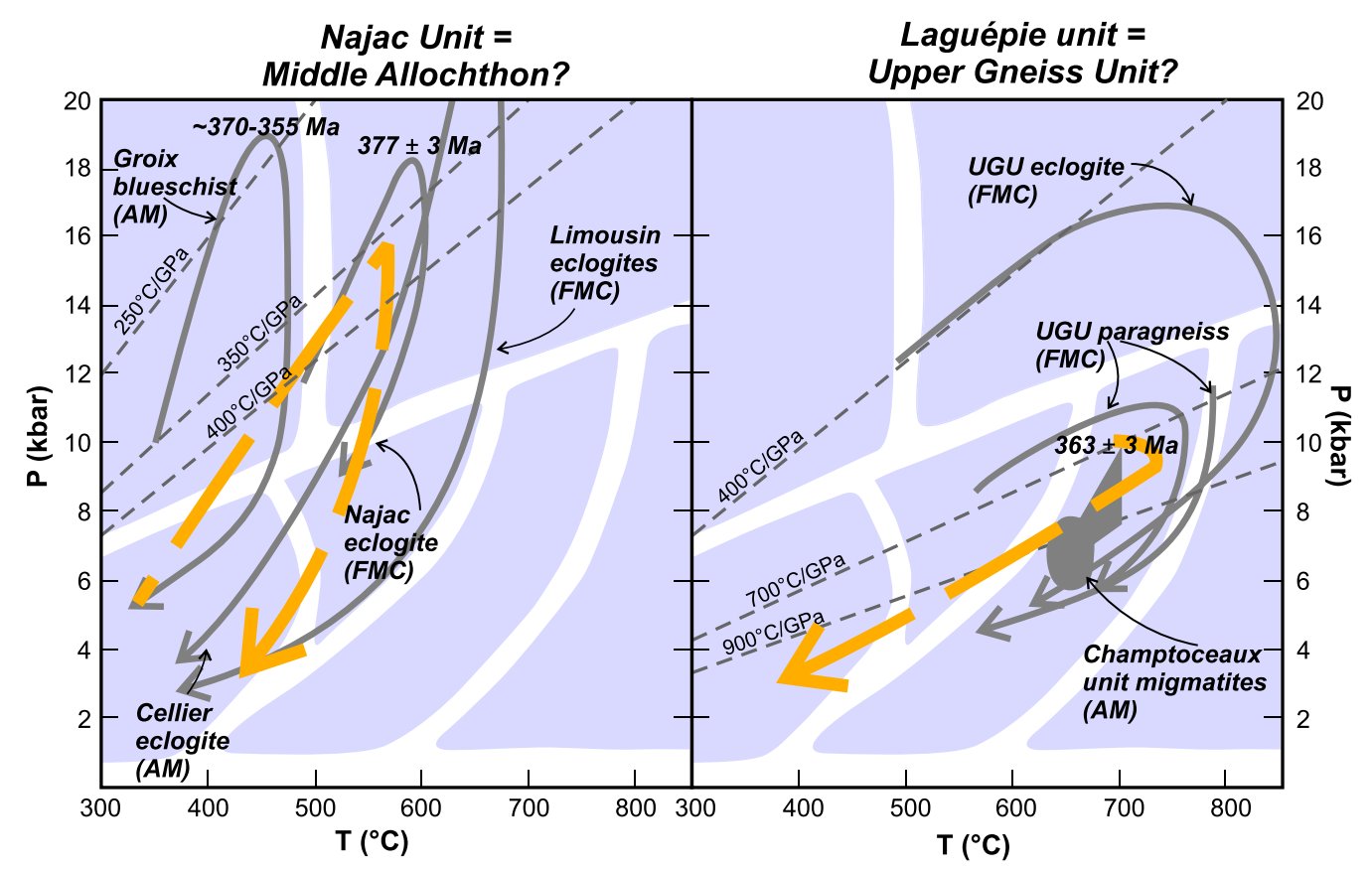

Fig. 9. Proposed P-T path (orange arrows) for the Najac and the Laguépie units. Grey P-T paths are from the literature: Groix blueschists from Ballèvre et al. (2003), Cellier éclogites from Ballèvre et al. (2014); Najac éclogite from Lotout et al. (2018); UGU eclogite from Bellot and Roig (2007); UGU paragneiss from Bellot and Roig (2007) and Schulz et al. (2009), Champtoceaux migmatites after Pitra et al. (2010). Age of the HP metamorphism in the Groix Island from Bosse et al. (2005), age of pressure peak in the Najac eclogite from Lotout et al. (2018).

large Carboniferous plutons (Bellot and Roig, 2007). Both the Lower Gneiss (Lower Allochthon by Santallier et al., 1994) and Upper Gneiss Units (Bellot and Roig, 2007; Lardeaux, 2014; called Middle Allochthon by Santallier et al., 1994) display evidences for pervasive recrystallization in the amphibolite facies, around $600-750{ }^{\circ} \mathrm{C}, 5-10 \mathrm{kbar}$ (see Faure et al., 2009; Do Couto et al., 2016) after a phase of high pressure metamorphism, mostly recorded in the UGU. The uppermost epizonal units (called Upper Allochthon by Santallier et al., 1994) are poorly characterized, they are mostly considered as greenschist facies meta-sedimentary and meta-igneous rocks (Roig et al., 1996; Lardeaux, 2014). The nappe stack in the southern Armorican massif is either described similarly to the FMC by Faure et al. $(2005,2008)$ or subdivided into various allochthons by Ballèvre et al. (2009, 2014). In both the FMC and AM, a Middle Allochthon has been defined on the basis of its structural position within the nappe stack and the metamorphic conditions recorded by its constitutive rocks. Berger et al. (2010a) described zoisite and kyanite eclogites $\left(\sim 660^{\circ} \mathrm{C}, 29 \mathrm{kbar}\right)$ exhumed at temperatures below $650^{\circ} \mathrm{C}$. They are located close to the contact between LGU and UGU and were included into a Middle Allochthon. Ballèvre et al. (2014) proposed to assign the Groix and Bois de Céné blueschists $\left(<570{ }^{\circ} \mathrm{C}\right.$, up to $17 \mathrm{kbar}$ and also devoid of recrystallization in the amphibolite facies, Ballèvre et al., 2003) to a Middle Allochthon but its structural position is uncertain and debated (see Ballèvre et al., 2009 and also Faure et al., 2005). A Middle Allochthon would thus define as a unit comprising cold HP rocks devoid of Late Devonian amphibolite facies recrystallization and located between LGU and UGU.
The Najac unit is often included within the Upper Gneiss Unit on maps published by several authors (Lardeaux, 2014; Faure et al., 2017; Lotout et al., 2018). However, the UGU, containing most of retrogressed eclogite lenses in the FMC (formed during the $420-400 \mathrm{Ma}$ D0 event of Faure et al., 2009), also include migmatitic paragneisses having experienced temperatures up to $700-750^{\circ} \mathrm{C}$ (Middle Devonian D1 event of Faure et al., 2008, 2009) followed by retrogression in the amphibolite facies (Upper Devonian D2 event; Faure et al., 2009). The P-T path of the Najac unit is unusual in the French Massif central (Fig. 9; see Bellot and Roig, 2007; Faure et al., 2009 and Lardeaux, 2014 for reviews on the metamorphic structure and evolution of the French Massif central). Rocks forming the Najac unit have not recorded the D1 and D2 amphibolite facies metamorphic phases preserved in LGU and UGU and instead preserve high-pressure, low temperature $\left(340{ }^{\circ} \mathrm{C} / \mathrm{GPa}\right.$ at peak pressure) event contemporaneous with a top-to-the-southeast sense of shear. High-pressure rocks included in the Middle Allochthon of the FMC and the AM display metamorphic evolutions similar to the one of the Najac unit, i.e. a HP stage followed by an isothermal exhumation path without recrystallization in the amphibolite facies (Berger et al., 2010a; Ballèvre et al., 2003, 2014). Delor et al. (1986) described glaucophane relics in Najac eclogites and already proposed that they belong to the same tectono-metamorphic unit than the Groix and Bois de Céné units in the Armorican massif. High-pressure rocks from these Middle Allochthon occurrences in Brittany (Guiraud et al., 1987; Ballèvre et al., 2003) are characterized by a cold high pressure metamorphism $\left(<500^{\circ}\right.$, up to $18 \mathrm{kbar} ; 7-8^{\circ} \mathrm{C} / \mathrm{km}$ ) followed by exhumation at low temperature $\left(<500^{\circ} \mathrm{C}\right)$ that compares to Najac micaschists 
(Fig. 9a). The base of the Lower Allochthon (Lower Gneiss Unit of Faure et al., 2005) unit in the Armorican massif also contains eclogitic lenses and HP orthogneiss (in the Cellier unit) having quite similar peak conditions $\left(600^{\circ} \mathrm{C}, 2 \mathrm{GPa}\right.$; $10{ }^{\circ} \mathrm{C} / \mathrm{km}$; Fig. 9a) (Ballèvre et al., 2014) when compared to the Najac unit. However, they cannot be considered as the lateral equivalent of the Najac unit as the latter clearly thrusts over the Lower Gneiss Unit (Fig. 1).

Published ages for HP metamorphism in the Middle Allochthon are not strictly equivalent in different locations. Lotout et al. (2018) performed multi-method dating (U-Pb zircon and apatite; Sm-Nd and Lu-Hf isochrons) on a retrogressed eclogite from Najac and obtained Upper Devonian ages (383-369 Ma) interpreted as the age of highpressure metamorphism. Sm-Nd, $\mathrm{Rb}-\mathrm{Sr}$ and $\mathrm{Ar}-\mathrm{Ar}$ geochronology by Bosse et al. (2005) also yielded $370-355 \mathrm{Ma}$ for high pressure metamorphism and exhumation of the Groix blueschists. Berger et al. (2010a) proposed that the age of HP metamorphism in Middle Allochthon of Limousin is Lower Devonian but this is based on questionable and sparse ages obtained on thin uranium-poor zircon rims surrounding uranium-rich Ordovician cores. Upper Devonian ( 380 Ma) ages were also obtained on these zircon rims but they were tentatively attributed to D1 Late-Devonian high temperature metamorphism recorded in Limousin (cf. Faure et al., 2008; Melleton et al., 2009) while the dated eclogite is almost not affected by retrogression. New careful analyses done in the zircon rims from the same sample investigated by Berger et al. (2010a) yielded younger Upper Devonian ages (work in progress).

Considering the metamorphic evolution, the age and the structural position (thrusting over the Lower Gneiss Unit) of the high-pressure Najac unit, we thus propose that it represents the lateral equivalent of the Groix and Bois de Céné unit in the Armorican massif and the Limousin eclogites of Berger et al. (2010a) and assign this unit to the Middle Allochthon Further exploration of phengitic, biotite-poor garnet micaschists and associated eclogites is needed in the French Massif central to better characterize a potential Middle Allochthon and to correlate it with well-known occurrences of the Armorican massif.

The Laguépie unit records amphibolite facies metamorphism peaking at $710-730{ }^{\circ} \mathrm{C}, 10 \mathrm{kbar}$, corresponding to metamorphic conditions obtained in the Upper Gneiss Unit elsewhere in the French Massif central (Burg et al., 1984; Bellot and Roig, 2007; Schulz, 2009; Lardeaux, 2014; Do Couto et al., 2016; Fig. 9b). The UGU hosts retrogressed eclogites enclosed into migmatitic paragneisses, formed during the D0 and D1 events, respectively (Faure et al., 2009; Melleton et al., 2009; Do Couto et al., 2016). High pressure metamorphism and partial melting were followed by retrogression in the amphibolite facies around $600-700{ }^{\circ} \mathrm{C}, 5-$ $10 \mathrm{kbar}$ during the Upper Devonian/Lower Carboniferous D2 event (Faure et al., 2009). Association of mafic and felsic rocks recrystallized in the amphibolite facies is common in the Leptyno-Amphibolite Complex (LAC), usually attributed to the UGU (see Ledru et al., 1989, 1994 and Lardeaux, 2014) and more rarely to the LGU (Bellot and Roig, 2007). Mafic rocks from the LAC often display relict assemblages attesting for eclogite and HP granulite facies metamorphism (Santallier et al., 1988) and their igneous precursors are thought to have been emplaced in an ocean-continent transition zone (Lardeaux, 2014). If the Laguépie unit belongs to the LAC, it must be envisaged that the some of the mafic-felsic associations can also originate after partial melting of a mafic precursor. The age of partial melting and felsic melt crystallization has been constrained at ca. $363 \pm 3 \mathrm{Ma}$ in the Laguépie unit. While Faure et al. (2009) usually ascribe the partial melting event to the 385-375 Ma Devonian D1 phase, $\mathrm{U}-\mathrm{Pb}$ dating indicates that amphibolite facies (up to $730^{\circ} \mathrm{C}$ ) partial melting at Laguépie occurred during Late Devonian. It was followed by top-to-the-north shearing under amphibolite to greenschist facies conditions probably during Lowermost Carboniferous corresponding to the kinematic proposed for the D2 event (Faure et al., 2017).

In the Armorican massif, robust P-T estimates by Pitra et al. (2010) yielded peak temperature above $650{ }^{\circ} \mathrm{C}$ at pressure conditions ranging from 8 to $11 \mathrm{kbar}$ for migmatitic paragneisses of the eclogite and HP orthogneiss bearing Champtoceaux unit. However the structural position of this units is debated: Faure et al. $(2005,2008)$ include it into the UGU by correlation with FMC occurrences; Ballèvre et al. (2009) and Pitra et al. (2010) place it at the base of an Upper Allochthon while the upper parts of this allochthon involve a Cadomian basement with low grade metasediments and ophiolites (Faure et al., 2005, 2008; Ballèvre et al., 2009; Ducassou et al., 2011). It is however included within the Lower Allochthon by Ballèvre et al. (2014) by correlation within Iberian massifs. The Laguépie and Champtoceaux units both yield peak temperature conditions around $700{ }^{\circ} \mathrm{C}$ and $10 \mathrm{kbar}$ (Fig. 9). Their metamorphic evolutions are thus more comparable to the Upper Gneiss Unit in FMC, as suggested by Faure et al. $(2005,2008)$. Considering the conditions and age of amphibolite facies metamorphism (363 Ma) along with the deformation post-dating the anatectic stage, the Laguépie units correlates with the LAC in the FMC and the Champtoceaux Unit in the AM, that we tentatively ascribe to the Upper Gneiss Unit as defined in the literature (see Lardeaux, 2014; Fig. 9).

\subsection{Geodynamic significance}

The results presented in this study and those published recently by Lotout et al. $(2018,2020)$ are not compatible with the subdivision in tectono-metamorphic phases proposed by Faure et al. $(2005,2008,2009)$. In these latter papers, the D0 phase correspond to the formation of HP units between 420 and $400 \mathrm{Ma}$ during the closure of an oceanic domain separating Gondwana and Armorica. However, Lotout et al. (2018) provided Upper Devonian ages for the Najac eclogites and Lotout et al. (2020) obtained Upper Devonian to Early Carboniferous ages for HP metamorphism in Lévézou. These data suggest that HP metamorphism is younger in southern French Massif central compared to other occurrences (Pin and Lancelot, 1982; Ducrot et al., 1983; Paquette et al., 1995). Furthermore, partial melting in UGU as recorded in the Laguépie unit is usually ascribed to the $385-375$ Ma D1 event by Faure et al. (2009) but it is dated at $363 \mathrm{Ma}$ at Laguépie. It is however affected by the Late Devonian/Lower Carboniferous D2 top-to-the-north shearing (Faure et al., 2017). These discrepancies suggest that either (i) new and old ages for HP 
metamorphism should be critically evaluated because dating HP metamorphism is a difficult and challenging task or (ii) metamorphic events are about $20 \mathrm{Myr}$ younger in southern French Massif central compared to northern parts or (iii) that final collision between Armorica and Gondwana occurred during Upper Devonian/Early Carboniferous and not Lower Devonian, as suggested by Lardeaux (2014) and Ballèvre et al. (2009, 2014).

If we consider that Upper Devonian HP/LT metamorphism (Lotout et al., 2018, 2020) is coeval with partial melting in UGU (Melleton et al., 2009; this study) and active margin magmatism as represented by tonalites and diorites intruding the UGU (375-355 Ma; Bernard-Griffiths et al., 1985; Shaw et al., 1993; Bertrand et al., 2001; Pin and Paquette, 2002); these data are compatible with an active subduction system forming a paired metamorphic belt during Late Devonian (Miyashiro, 1967; Brown, 2006). The Najac unit, comprising a basic/ultrabasic intrusion within orthogneisses and micaschists all metamorphosed under eclogite facies conditions, either represents fragments of a continental lower plate or the accretionary prism in the subduction system (proposed for the Groix blueschists, Ballèvre et al., 2014). The UGU, and accordingly, the Laguépie unit, are, in this proposition, part of the upper plate of the subduction system, similarly to what has been proposed by Lardeaux (2014) and Lardeaux et al. (2014). Nappe stacking that caused superimposition of the Najac and Laguépie units occurred after $363 \mathrm{Ma}$, probably during the Early Carboniferous 345-335 Ma D3 phase of Faure et al. (2009) because the Najac micaschists were not affected by the Late Devonian $700^{\circ} \mathrm{C} / 10 \mathrm{kbar}$ metamorphism observed at Laguépie.

\section{Conclusion}

Petrological investigations on metamorphic samples from the Najac and Laguépie units in the southwestern FMC reveal two distinct P-T evolutions. The Najac unit is characterized by syn-kinematic eclogitic metamorphism in micaschists and basic rocks implying subduction of a continental margin at the end of the Devonian (around $377 \mathrm{Ma}$ ) followed by cold exhumation in the greenschist facies. The Laguépie unit records amphibolite facies metamorphism $\left(710^{\circ} \mathrm{C}, 10 \mathrm{kbar}\right)$ dated at $363 \mathrm{Ma}$ and later affected by deformation and retrogression under amphibolite to greenschist facies conditions. These two units were formerly grouped into the leptyno-amphibolite complex belonging to the Upper Gneiss Unit. Comparison with tectono-metamorphic units in the French Massif central and the Armorican massifs suggest that the Najac unit can be integrated into the HP/LT Middle Allochthon while the Laguépie unit belongs to the Upper Gneiss Unit. The French Massif central consequently preserves the remnants of an Upper Devonian paired metamorphic belt, where the Middle Allochthon represent subducted material attached to the slab or within an accretionary prism while the Upper Gneiss Unit was located within the upper plate of the subduction system. Lower Carboniferous continental collision further led to the stacking of metamorphic units with contrasted pre-Carboniferous histories. The stack, in its current configuration, is showing an apparent inverted metamorphic gradient, well expressed in the Rouergue domain.
The structure of the tectono-metamorphic units near Najac can be considered as a reference for further studies on the structure and evolution of metamorphic units preserved in the French Massif central. Future investigations should focus on obtaining precise P-T-t paths on pre-Carboniferous metamorphic units belonging to the FMC and exploration of phengitebearing biotite-poor garnet micaschists (locally enclosing eclogites) possibly marking a still poorly defined Middle Allochthon. Altogether, these results should be used to propose an integrated tectono-metamorphic framework that can be useful to test the different geodynamic scenarios proposed for the Variscan orogeny in Western Europe.

\section{Supplementary material}

Table S1. Tables of mineral chemistry for samples of Najac micaschists and Laguépie amphibolites.

The Supplementary material is available at https://www.bsgf. $\mathrm{fr} / / 10.1051 / \mathrm{bsgf} / 2020033 / \mathrm{olm}$.

Acknowledgments. This study was partly funded by a SYSTER-TELLUS grant from the INSU-CNRS. Stays of $\mathrm{AB}$ at Toulouse were funded by the FP7 IRSES MEDYNA project and an excellence EIFFEL fellowship. Fabienne de Parseval is thanked for making thin sections; Philippe de Parseval and Sophie Gouy supervised the electron microprobe analyses and Thierry Aigouy helped with SEM observations. We acknowledge comments by Michel Faure and an anonymous reviewer as well as editorial handling by JeanMarc Lardeaux, Olivier Averbuch and Laurent Jolivet.

\section{References}

Ballèvre M, Pitra P, Bohn M. 2003. Lawsonite growth in the epidote blueschists from the Ile de Groix (Armorican Massif, France): a potential geobarometer. Journal of Metamorphic Geology 21: 723-735.

Ballèvre M, Bosse V, Ducassou C, Pitra P. 2009. Palaeozoic history of the Armorican Massif: Models for the tectonic evolution of the suture zones. Comptes rendus géoscience 341: 174-201.

Ballèvre M, Martínez Catalán JR, López-Carmona A, Pitra P, Abati J, Fernández RD, et al. 2014. Correlation of the nappe stack in the Ibero-Armorican arc across the Bay of Biscay: a joint FrenchSpanish project. Geological Society of London, Special Publications 405: 77-103.

Bellot JP, Roig JY. 2007. Episodic exhumation of HP rocks inferred from structural data and P-T paths from the Southwestern Massif central (Variscan belt, France). Journal of Structural Geology 29: 1538-1557.

Berger J, Féménias O, Ohnenstetter D, Bruguier O, Plissart G, Mercier JCC, et al. 2010a. New occurrence of UHP eclogites in Limousin (French Massif central): age, tectonic setting and fluidrock interactions. Lithos 118: 365-382.

Berger J, Féménias O, Ohnenstetter D, Plissart G, Mercier JC. 2010 b. Origin and tectonic significance of corundum-kyanite-sapphirine amphibolites from the Variscan French Massif central. Journal of Metamorphic Geology 28: 341-360.

Bernard-Griffiths J, Gebauer D, Grunenfelder M, Piboule M. 1985. The tonalite belt of Limousin (French Central Massif); U-Pb zircon ages and geotectonic implications. Bulletin de la Société géologique de France I: 523-529. 
Bertrand J-M, Leterrier J, Cuney M, Brouand M, Stussi J-M. 2001. Géochronologie $\mathrm{U}-\mathrm{Pb}$ sur zircons de granitoïdes du Confolentais, du massif de Charroux-Civray (seuil du Poitou) et de Vendée. Géologie de la France 1-2: 167-189.

Bodinier J-L, Burg J-P. 1981. Évolution métamorphique et tectonique des séries cristallophylliennes du Rouergue occidental : mise en évidence d'un chevauchement dans la région de Najac (Aveyron). Bulletin du Bureau de recherches géologiques et minières 4: 315336.

Bodinier J-L, Giraud A, Dupuy C, Leyreloup A, Dostal J. 1986. Caractérisation géochimique des métabasites associées à la suture méridionale hercynienne : massif central français et Chamrousse (Alpes). Bulletin de la Société géologique de France 8: 115-123.

Bosse V, Feraud G, Ruffet G, Ballevre M, Peucat JJ, De Jong K. 2000. Late Devonian subduction and early-orogenic exhumation of eclogite-facies rocks from the Champtoceaux Complex (Variscan belt, France). Geological Journal 35: 297-325.

Bosse V, Féraud G, Ballèvre M, Peucat J-J, Corsini M. 2005. Rb-Sr and $40 \mathrm{Ar} / 39 \mathrm{Ar}$ ages in blueschists from the Île de Groix (Armorican Massif, France): implications for closure mechanisms in isotopic systems. Chemical Geology 220: 21-45.

Bosch D, Garrido CJ, Bruguier O, Dhuime B, Bodinier JL, PadronNavarta JA, Galland B. 2011. Building an island-arc crustal section: time constraints from a LA-ICP-MS zircon study. Earth and Planetary Science Letters 309: 268-279.

Brown M. 2006. Duality of thermal regimes is the distinctive characteristic of plate tectonics since the Neoarchean. Geology 34: 961-964.

Burg J-P., Matte P, Leyreloup A, Marchand J. 1984. Inverted metamorphic zonation and large-scale thrusting in the Variscan Belt: an example in the French Massif central. Geological Society of London, Special Publications 14: 47-61.

Burg J-P, Leyreloup AF, Romney F, Delor CP. 1989a. Inverted metamorphic zonation and Variscan thrust tectonics in the Rouergue area (Massif central, France): P-T-t record from mineral to regional scale. Geological Society of London, Special Publications 43: 423-439.

Burg J-P, Alabouvette B, Leyreloup A-F, Pélissié T, Astruc JG, Lefavrais-Raymond A, et al. 1989b. Notice explicative, Carte géol. France (1/50 000), feuille Villefranche-de-Rouergue (882). Orléans: BRGM, 79 p.

Burg J-P, Vanderhaeghe O. 1993. Structures and way-up criteria in migmatites, with application to the Velay dome (French Massif central). Journal of Structural Geology 15: 1293-1301.

Collomb P. 1970. Étude géologique du Rouergue cristallin. Mémoires pour servir à l'explication de la carte géologique détaillée de la France. Paris: Imprimerie nationale, 419 p.

Connolly JAD. 2009. The geodynamic equation of state: what and how. Geochemistry, Geophysics, Geosystems 10: q10014.

Coggon R, Holland TJB. 2002. Mixing properties of phengitic micas and revised garnet-phengite thermobarometers. Journal of Metamorphic Geology 20: 683-696.

Corfu F, Hanchar JM, Hoskin PWO, Kinny P. 2003. Atlas of zircon textures. Reviews in Mineralogy and Geochemistry 53: 469-500.

Delor C., Leyreloup A, Bodinier J-L, Burg J-P. 1986. Découverte d'éclogites à glaucophane dans la klippe de Najac (Massif central, France) : nouveaux témoins océaniques d'un stade haute pression dans la chaîne de collision varisque. Comptes rendus de l'Académie des sciences de Paris, série II 302: 739-744.

Delor C, Burg J-P, Guiraud M, Leyreloup A. 1987. Les métapélites à phengite-chloritoïde-grenat-staurotide-disthène de la klippe de Najac-Carmaux : nouveaux marqueurs d'un métamorphisme de haute-pression vaisque en Rouergue occidental. Comptes rendus de l'Académie des sciences de Paris, série II 305: 589-595.
Do Couto D, Faure M, Augier R, Cocherie A, Rossi P, Li X-H, et al. 2016. Monazite U-Th-Pb EPMA and zircon U-Pb SIMS chronological constraints on the tectonic, metamorphic, and thermal events in the inner part of the Variscan orogen, example from the Sioule series, French Massif Central. International Journal of Earth Sciences 105: 557-579.

Dubuisson G, Hirn A, Girardeau J, Mercier JCC, Veinante JL. 1988. Multiple Variscan Nappes in Limousin, Western Massif central, France - Geophysical constraints to the geological model and geodynamic implications. Tectonophysics 147: 19-31.

Ducassou C, Ballèvre M, Lardeux H, Robin C. 2011. Evidence for pre-orogenic, Early Devonian rifting in the Variscan belt: stratigraphy and structure of the Palaeozoic cover of the Mauges Unit (Upper Allochthon, Armorican massif, France). International Journal of Earth Sciences 100: 1451-1475.

Ducrot J, Lancelot J-R., Marchand J. 1983. Datation U-Pb sur zircons de l'éclogite de La Borie (Haut-Allier, France) et conséquences sur l'évolution anté-hercynienne de l'Europe occidentale. Earth and Planetary Science Letters 62: 385-394.

Ernst WG. 2001. Subduction, ultrahigh-pressure metamorphism and regurgitation of buoyant crustal slices - implications for arcs and continental growth. Physics of the Earth and Planetary Interiors 127: 253-275.

Faure M, Bé Mézème E, Duguet M, Cartier C, Talbot JY. 2005. Paleozoic tectonic evolution of medio-Europa from the example of the French Massif Central and Massif Armoricain. Journal of the Virtual Explorer 19: 1-25.

Faure M, Bé Mézème E, Cocherie A, Rossi P, Chemenda A, Boutelier D. 2008. Devonian geodynamic evolution of the Variscan belt, insights from the French Massif Central and Massif Armoricain. Tectonics 27: TC2005.

Faure M, Lardeaux J-M, Ledru P. 2009. A review of the pre-Permian geology of the Variscan French Massif central. Comptes rendus géoscience 341: 202-213.

Faure M, Li X-H, Lin W. 2017. The northwest-directed "Bretonian phase" in the French Variscan Belt (Massif central and Massif Armoricain): a consequence of the Early Carboniferous GondwanaLaurussia collision. Comptes rendus géoscience 349: 126-136.

Green ECR, White RW, Diener JFA, Powell R, Holland TJB, Palin RM. 2016. Activity-composition relations for the calculation of partial melting equilibria in metabasic rocks. Journal of Metamorphic Geology 34: 845-869.

Guiraud M, Burg J-P, Powell R. 1987. Evidence for a Variscan suture zone in the Vendée, France: a petrological study of blueschist facies rocks from Bois de Cené. Journal of Metamorphic Geology 5: 225-237.

Holland TJB, Blundy J. 1994. Non-ideal interactions in calcic amphiboles and their bearing on amphibole-plagioclase thermometry. Contributions to Mineralogy and Petrolology 116: 433-447.

Holland TJB, Powell R. 1998. An internally consistent thermodynamic data set for phases of petrological interest. Journal of Metamorphic Geology 16: 309-343.

Holland TJB, Powell R. 2011. An improved and extended internally consistent thermodynamic dataset for phases of petrological interest, involving a new equation of state for solids. Journal of Metamorphic Geology 29: 333-383.

Hydmann RD, Currie CA, Mazzotti SP. 2005. Subduction zone backarcs, mobile belts and orogenic belt. GSA Today 15: 4-10.

Jackson SE, Pearson NJ, Griffin WL, Belousova EA. 2004. The application of laser ablation-inductively coupled plasma-mass spectrometry to in situ U-Pb zircon geochronology. Chemical Geology 211: 47-69.

Kohn MJ, Spear FS. 1990. Two new geobarometers for garnet amphibolites, with applications to Southeastern Vermont. American Mineralogist 75: 89-96. 
Lardeaux J-M. 2014. Deciphering orogeny: a metamorphic perspective. Examples from European Alpine and Variscan belts: part II: variscan metamorphism in the French Massif central - A review. Bulletin de la Société géologique de France 185: 281-310.

Lardeaux J-M, Schulmann K, Faure M, Janousek V, Lexa O, Skrzypek E, et al. 2014. The Moldanubian Zone in French Massif Central, Vosges/Schwarzwald and Bohemian Massif revisited: differences and similarities. Geological Society of London, Special Publications 405: 7-44.

Leake BE, Woolley AR, Birch WD, Gilbert MC, Grice JD, Hawthorne FC, et al. 1997. Nomenclature of amphiboles Report of the subcommittee on Amphiboles of the International Mineralogical Association Commission on New Minerals and Mineral Names. European Journal of Mineralogy 9: 623-651.

Ledru P, Lardeaux JM, Santallier D, Autran A, Quenardel JM, Floch JP, et al. 1989. Where are the Nappes in the French Massif central. Bulletin de la Société géologique de France 5: 605-618.

Ledru P, Autran A, Santallier D. 1994. Lithostratigraphy of Variscan Terranes in the French Massif central: a basis for paleogeographical reconstruction. In: Keppie JD, ed. Pre-Mesozoic Geology in France and Related Areas. Berlin, Heidelberg: Springer Berlin Heidelberg, pp. 276-288.

Lotout C, Pitra P, Poujol M, Anczkiewicz R, Van Den Driessche J. 2018. Timing and duration of Variscan high-pressure metamorphism in the French Massif central: a multimethod geochronological study from the Najac Massif. Lithos 308-309: 381-394.

Lotout C, Poujol M, Pitra P, Anczkiewicz R, Van Den Driessche J. 2020. From burial to exhumation: emplacement and metamorphism of mafic eclogitic terranes constrained through multimethod petrochronology, case study from the Lévézou Massif (French Massif Central, Variscan Belt). Journal of Petrology, in press.

Melleton J, Faure M, Cocherie A. 2009. Monazite U-Th/Pb chemical dating of the Early Carboniferous syn-kinematic MP/MT metamorphism in the Variscan French Massif central. Bulletin de la Société géologique de France 180: 283-292.

Miyashiro A. 1967. Orogeny, regional metamorphism, and magmatism in the Japanese islands. Meddelelser fra Dansk Geologisk Forening 17: 390-446.

Newton RC, Charlu TV, Kleppa OJ. 1980. Thermochemistry of the high structural state plagioclases. Geochimica Et Cosmochimica Acta 44: 933-941.

Paquette J-L, Monchoux P, Couturier M. 1995. Geochemical and isotopic study of a norite-eclogite transition in the European Variscan belt: implications for U-Pb zircon systematics in metabasic rocks. Geochimica et Cosmochimica Acta 59: 16111622.

Paquette JL, Ballèvre M, Peucat JJ, Cornen G. 2017. From opening to subduction of an oceanic domain constrained by LA-ICP-MS U-Pb zircon dating (Variscan belt, Southern Armorican Massif, France). Lithos 294-295: 418-437.

Peacock SM. 1987. Creation and preservation of subduction-related inverted metamorphic gradients. Journal of Geophysical Research 92(B12): 12763-12781.

Pin C, Lancelot J. 1982. U-Pb dating of an early paleozoic bimodal magmatism in the french Massif Central and of its further metamorphic evolution. Contributions to Mineralogy and Petrology 79: 1-12.

Pin C, Paquette JL. 2002. Sr-Nd isotope and trace element evidence for a Late Devonian active margin in northern Massif-Central (France). Geodinamica Acta 15: 63-77.

Pitra P, Ballèvre M, Ruffet G. 2010. Inverted metamorphic field gradient towards a Variscan suture zone (Champtoceaux Complex, Armorican Massif, France). Journal of Metamorphic Geology 28: 183-208.

Roig JY, Faure M, Ledru P. 1996. Polyphase wrench tectonics in the southern french Massif Central: kinematic inferences from pre-and syntectonic granitoids. Geologische Rundschau 85: 138-153.

Santallier D, Briand B, Ménot RP, Piboule M. 1988. Les complexes leptyno-amphiboliques (C.I.A.) ; revue critique et suggestions pour un meilleur emploi de ce terme. Bulletin de la Société géologique de France 4: 3-12.

Santallier DS, Lardeaux J-M, Marchand J, Marignac C. 1994. Metamorphism. In: Keppie JD, ed. Pre-Mesozoic Geology in France and Related Areas. Berlin, Heidelberg: Springer Berlin Heidelberg, pp. 324-340.

Shaw A, Downes H, Thirlwall MF. 1993. The quartz-diorites of Limousin: elemental and isotopic evidence for Devono-Carboniferous subduction in the Hercynian belt of the French Massif Central. Chemical Geology 107: 1-18.

Schulz B. 2009. EMP-monazite age controls on P-T paths of garnet metapelites in the Variscan inverted metamorphic sequence of $\mathrm{La}$ Sioule, French Massif central. Bulletin de la Société géologique de France 180: 271-282.

Tajcmanova L, Connolly JAD, Cesare B. 2009. A thermodynamic model for titanium and ferric iron solution in biotite. Journal of Metamorphic Geology 27: 153-165.

Vermeesch P. 2018. IsoplotR: a free and open toolbox for geochronology. Geoscience Frontiers 9: 1479-1493.

Cite this article as: Benmammar A, Berger J, Triantafyllou A, Duchene S, Bendaoud A, Baele J-M, Bruguier O, Diot H. 2020. Pressuretemperature conditions and significance of Upper Devonian eclogite and amphibolite facies metamorphisms in southern French Massif central, BSGF - Earth Sciences Bulletin 191: 28. 